\title{
Integration of $\mathrm{P} 2 \mathrm{Y}$ receptor-activated signal transduction pathways in $G$ protein-dependent signalling networks
}

\author{
Kristof Van Kolen • Herman Slegers \\ Received: 19 July 2005 / Accepted: 17 March 2006 / Published online: 7 June 2006 \\ (C) Springer Science + Business Media B.V. 2006
}

\begin{abstract}
The role of nucleotides in intracellular energy provision and nucleic acid synthesis has been known for a long time. In the past decade, evidence has been presented that, in addition to these functions, nucleotides are also autocrine and paracrine messenger molecules that initiate and regulate a large number of biological processes. The actions of extracellular nucleotides are mediated by ionotropic P2X and metabotropic $\mathrm{P} 2 \mathrm{Y}$ receptors, while hydrolysis by ecto-enzymes modulates the initial signal. An increasing number of studies have been performed to obtain information on the signal transduction pathways activated by nucleotide receptors. The development of specific and stable purinergic receptor agonists and antagonists with therapeutical potential largely contributed to the identification of receptors responsible for nucleotide-activated pathways. This article reviews the signal transduction pathways activated by P2Y receptors, the involved second messenger systems, GTPases and protein kinases, as well as recent findings concerning P2Y receptor signalling in C6 glioma cells. Besides vertical signal transduction, lateral cross-talks with pathways activated by other $\mathrm{G}$ protein-coupled receptors and growth factor receptors are discussed.
\end{abstract}

Key words C6 glioma - ERK · P2Y receptors · PKB . transactivation $\cdot$ tyrosine kinases

K. Van Kolen $\cdot$ H. Slegers $(\bowtie)$

Department of Biomedical Sciences, Cellular Biochemistry, University of Antwerp,

Universiteitsplein 1,

2610 Wilrijk-Antwerpen, Belgium

e-mail: herman.slegers@ua.ac.be

K. Van Kolen

CNS research, Johnson \& Johnson, PRD,

Janssen Pharmaceutica,

Beerse, Belgium

\author{
Abbreviations \\ AC adenylate cyclase \\ $\mathrm{Ap}_{3} \mathrm{~A} \quad \mathrm{P}^{1}, \mathrm{P}^{3}$-di(adenosine-5')triphosphate \\ $\mathrm{Ap}_{4} \mathrm{~A} \quad \mathrm{P}^{1}, \mathrm{P}^{4}$-di(adenosine- $\left.5^{\prime}\right)$ tetraphosphate \\ $\mathrm{AR}$ adrenergic receptor \\ COX cyclooxygenase \\ DAG diacylglycerol \\ ERK extracellular signal-regulated kinase \\ GFAP glial fibrillary acidic protein \\ GPCR G protein-coupled receptor \\ HT hydroxytryptamine \\ $\mathrm{IP}_{3} \quad$ inositol $(1,4,5)$-triphosphate \\ PAP adenosine- $3^{\prime}, 5^{\prime}$-biphosphate \\ PI phosphatidylinositol \\ PL phospholipase \\ PI 3-K phosphatidylinositol 3-kinase \\ PPADS pyridoxalphosphate-6-azophenyl-2', \\ $4^{\prime}$-disulphonate \\ Pyk2 proline-rich tyrosine kinase 2 \\ RKIP Raf kinase inhibitory protein \\ RTK receptor tyrosine kinase
}

\section{Introduction}

Pharmacological properties of P2Y receptors

Extracellular actions of adenine nucleotides were initially characterised in the cardiovascular system by Drury and Szent-Gyorgyi [1]. It took more than four decades before the concept of purinergic signalling was accepted, but now it is well established that nucleotides initiate and regulate a variety of biological processes, including neurotransmission, inflammation, regulation of blood pressure, platelet aggregation, cell growth and differentiation (Abbracchio et al. [2]; Burnstock and Williams [3]; Burnstock [4]; Ralevic and Burnstock [5]). 
Nucleotides are released in the extracellular fluid by cell lysis, exocytosis, secretion of granules, efflux and upon cellular stress such as changes in osmolarity and mechanical perturbations. Once released, they mediate their effect by stimulation of nucleotide receptors.

Based on pharmacological properties, the first suggestion for the existence of ionotropic $\mathrm{P} 2 \mathrm{X}$ receptors and metabotropic $\mathrm{P} 2 \mathrm{Y}$ receptors was made by Burnstock and Kennedy [6]. After cloning, multiple subtypes of P2X and P2Y receptors were characterised unambiguously (Abbracchio and Burnstock [7] Burnstock and Williams [3]; Fredholm et al. [8]).

Up to now, the $\mathrm{P} 2 \mathrm{Y}$ receptor family comprises at least eight subtypes, $\mathrm{P} 2 \mathrm{Y}_{1}, \mathrm{P}_{2} \mathrm{Y}_{2}, \mathrm{P}_{2} \mathrm{Y}_{4}, \mathrm{P}_{2} \mathrm{Y}_{6}, \mathrm{P}_{2} \mathrm{Y}_{11}, \mathrm{P}_{2} \mathrm{Y}_{12}$, $\mathrm{P}_{2} \mathrm{Y}_{13}$ and the recently identified $\mathrm{P}_{2} \mathrm{Y}_{14}$ receptor (Ralevic and Burnstock, [5] Abbracchio et al. [9]; Communi et al. [10]; Hollopeter et al. [11]; Zhang et al. [12]). According to the agonist profile, P2Y receptors can be subdivided into receptors responding to adenine mono- and dinucleotides $\left(\mathrm{P}_{2} \mathrm{Y}_{1}, \mathrm{P}_{2} \mathrm{Y}_{11}\right.$, $\left.\mathrm{P}_{2} \mathrm{Y}_{12}, \mathrm{P}_{2} \mathrm{Y}_{13}\right)$, and to uridine nucleotides $\left(\mathrm{P}_{2} \mathrm{Y}_{4}\right.$, $\mathrm{P}^{2} \mathrm{Y}_{6}$ ), and receptors for adenine and uridine nucleo- tides $\left(\mathrm{P}_{2} \mathrm{Y}_{2}\right)$. The pharmacological profile of the recently cloned $\mathrm{P}_{2} \mathrm{Y}_{14}$ receptor is distinct from the other P2Y receptors since UDP-glucose, UDP-galactose, UDP-glucuronic acid and UDP-N-acetylglucosamine are specific ligands of this receptor (Chambers et al. [13]). Natural P2Y receptor ligands do not exclusively bind to one receptor subtype. ADP is an agonist of $\mathrm{P}_{2} \mathrm{Y}_{1}, \mathrm{P}_{2} \mathrm{Y}_{12}$ and $\mathrm{P} 2 \mathrm{Y}_{13}$ receptors, whereas ATP is a full agonist of $\mathrm{P} 2 \mathrm{Y}_{2}$ and $\mathrm{P} 2 \mathrm{Y}_{11}$, but a partial agonist or antagonist of $\mathrm{P}_{2} \mathrm{Y}_{1}, \mathrm{P}_{2} \mathrm{Y}_{12}$ and $\mathrm{P} 2 \mathrm{Y}_{13}$ receptors. Although the pharmacological properties of P2Y receptors (Table 1) are well conserved between species, some remarkable differences have been observed. While UTP acts as an agonist of both human and rat $\mathrm{P}_{2} \mathrm{Y}_{4}$ receptors, ATP is a potent agonist of the rat $\mathrm{P}_{2} \mathrm{Y}_{4}$, but an antagonist of the human orthologue. Mutational analysis revealed that the second extracellular loop of the $\mathrm{P}_{2} \mathrm{Y}_{4}$ receptor is responsible for the opposing effect of ATP in both species (Herold et al. [14]). A similar phenomenon is observed when human and canine $\mathrm{P}_{2} \mathrm{Y}_{11}$ receptors were stably expressed in CHO-K1 and 1321N1 astrocytoma cells. Whereas the

Table 1 Pharmacological profile of P2Y receptors and second messenger systems.

\begin{tabular}{|c|c|c|c|c|}
\hline & Agonists & Antagonists & Effector & G protein \\
\hline $\mathrm{P} 2 \mathrm{Y}_{1}$ & $\begin{array}{l}\text { 2MeSADP, ADP, ADP } \beta S \\
\mathrm{Ap}_{3} \mathrm{~A}, \mathrm{MRS} 2365\end{array}$ & $\begin{array}{l}\text { Suramin, PPADS, PAP, MRS2179, MRS2216, } \\
\text { MRS2279, MRS2500, MRS } 2603\end{array}$ & $\mathrm{PLC}, \mathrm{I}_{\mathrm{K}, \mathrm{Ca}}$ & $\mathrm{G}_{\mathrm{q}} / \mathrm{G}_{11 / 12}$ \\
\hline $\mathrm{P} 2 \mathrm{Y}_{2}$ & $\begin{array}{l}\text { UTP } \gamma \mathrm{S}, \mathrm{ATP} \gamma \mathrm{S}, \mathrm{UTP}, \mathrm{ATP} \\
\text { INS37217, } \mathrm{Ap}_{4} \mathrm{~A}\end{array}$ & Suramin & PLC, $\mathrm{I}_{\mathrm{K}, \mathrm{Ca}}$ & $\mathrm{G}_{\mathrm{i}} / \mathrm{G}_{\mathrm{q}}$ \\
\hline $\mathrm{P} 2 \mathrm{Y}_{4}$ & $\mathrm{UTP} \gamma \mathrm{S}, \mathrm{UTP}, \mathrm{ATP}^{\mathrm{a}}$ & $\mathrm{ATP}^{\mathrm{a}}$, PPADS & PLC, $\mathrm{I}_{\mathrm{K}}$ & $\mathrm{G}_{\mathrm{q}} / \mathrm{G}_{11 / 12}$ \\
\hline $\mathrm{P} 2 \mathrm{Y}_{6}$ & UDP $\beta S$, UDP, UTP, INS48823 & PPADS, suramin, MRS2567 & PLC, $\mathrm{I}_{\mathrm{K}}$ & $\mathrm{G}_{\mathrm{q}} / \mathrm{G}_{11 / 12}$ \\
\hline $\mathrm{P}_{2} \mathrm{Y}_{11}$ & $\mathrm{ATP} \alpha \mathrm{S}, \mathrm{ATP} \gamma \mathrm{S}, \mathrm{ATP}$ & Suramin & AC, PLC & $\mathrm{G}_{\mathrm{q}} / \mathrm{G}_{\mathrm{s}}$ \\
\hline $\mathrm{P} 2 \mathrm{Y}_{12}$ & $\begin{array}{l}2 \mathrm{MeSADP}, \mathrm{ADP}, \mathrm{Ap}_{3} \mathrm{~A}, \mathrm{ATP} \\
\qquad \mathrm{Ap}_{4} \mathrm{~A}\end{array}$ & $\begin{array}{l}\text { AR-C69931MX, AR-C67085, AR-C78511KF, } \\
\text { clopidogrel, 2MeSAMP, DIDS, suramin, MRS2395 }\end{array}$ & $\mathrm{AC}, \mathrm{I}_{\mathrm{K}, \mathrm{Ca}}$ & $\mathrm{G}_{\mathrm{i} / \mathrm{o}}$ \\
\hline $\mathrm{P} 2 \mathrm{Y}_{13}$ & 2MeSADP, $\mathrm{ADP}, \mathrm{Ap}_{3} \mathrm{~A}, \mathrm{ATP}$ & $\begin{array}{l}\text { AR-C69931MX, Ap } 4 \text { A, PPADS, suramin, MRS2211, } \\
\text { MRS2603 }\end{array}$ & $\mathrm{AC}, \mathrm{PLC}, \mathrm{I}_{\mathrm{Ca}}$ & $\mathrm{G}_{\mathrm{i}} / \mathrm{G}_{\mathrm{q}}$ \\
\hline $\mathrm{P}_{2} \mathrm{Y}_{14}$ & $\begin{array}{l}\text { UDP-glucose, UDP-galactose, } \\
\text { UDP-glucuronic acid, } \\
\text { UDP-N-acetylglucosamine }\end{array}$ & & $\mathrm{AC}, \mathrm{I}_{\mathrm{Ca}}$ & $\mathrm{G}_{\mathrm{i}}$ \\
\hline
\end{tabular}

${ }^{\text {a }}$ ATP acts as an agonist of the rat $\mathrm{P}_{2} \mathrm{Y}_{4}$ but as an antagonist of the human $\mathrm{P}_{2} \mathrm{Y}_{4}$ receptor (Herold et al [14]). Reactive blue 2 is not included in the list since it displays lack of specificity towards the different P2Y subtypes. References: Abbracchio et al. [9]; Communi et al. [10, 191]; Chambers et al. [13]; Claes and Slegers [17]; Kim et al. [26]; Xu et al. [27]; Boyer et al. [38, 189, 190]; Grobben et al. [40]; Marteau et al. [47]; Filippov et al. [57-60, 63]; Simon et al. [61]; Wirkner et al. [62]; Korcok et al. [192]; Muller [193]; Skelton et al. [194]; Yerxa et al. [195]; Jacobson et al. [196]; von Kügelgen [197]. Abbreviations: $\mathrm{Ap}_{3} \mathrm{~A}, \mathrm{P}^{1}, \mathrm{P}^{3}$-di(adenosine- $\left.5^{\prime}\right)$ triphosphate; $\mathrm{Ap}_{4} \mathrm{~A}, \mathrm{P}^{1}, \mathrm{P}^{4}$-di(adenosine- $\left.5^{\prime}\right)$ tetraphosphate; ARC69931MX, N ${ }^{6}$-(2-methylthioethyl)-2-(3,3,3-trifluoropropylthio) $-\beta, \gamma$-dichloromethylene ATP; AR-C67085, 2-propylthio-D- $\beta \gamma$ dichloromethylene adenosine 5'-triphosphate; AR-C78511KF, (E)-N-[1-[7-(hexylamino)-5-(propylthio)-3H-1,2,3-triazolo-[4,5-d]-pyrimidin-3-yl]-1,5,6-trideoxy- $\beta$-D-ribo-hept-5-enofuranuronoyl]-L-aspartic acid monoammonium salt; DIDS, 4,4'-diisothiocyanatostilbene-2, $2^{\prime}$-disulphonic acid; INS37217 [P(1)-(uridine 5')-P (4)-( $2^{\prime}$-deoxycytidine $\left.5^{\prime}\right)$ tetraphosphate tetrasodium salt; INS48823 $\mathrm{P}^{1}$-((2-benzyl-1, 3-dioxolo-4-yl)uridine $\left.5^{\prime}\right) \mathrm{P}^{3}$-(uridine $5^{\prime}$ ) triphosphate; MRS2179, $\mathrm{N}^{6}$ methyl-2'-deoxyadenosine- $3^{\prime}, 5^{\prime}$-bisphosphate; MRS2211, pyridoxal- $5^{\prime}$ phosphate-6-azo-(2-chloro-5-nitrophenyl)-2,4-disulphonate; MRS2216, $2^{\prime}$-deoxy-2-chloro- $N^{6}$-methyladenosine-3', $5^{\prime}$-bisphosphate; MRS2279, 2-chloro- $\mathrm{N}^{6}$-methyl-(N)-methanocarba-2'-deoxyadenosine $3^{\prime}, 5^{\prime}$-bisphosphate; MRS2365, [(1'S, $\left.2^{\prime} \mathrm{R}, 3^{\prime} \mathrm{S}, 4^{\prime} \mathrm{R}, 5^{\prime} \mathrm{S}\right)-4-[(6$-amino-2-methylthio9H-purin-9-yl)-1-diphosphoryloxymethyl]bicyclo[3.1.0] hexane-2, 3-diol]; MRS2395, 2-dimethyl-propionic acid-3-(2-chloro-6-methylaminopurin9-yl)-2-(2,2-dimethylpropionyloxy-methyl)-propylester; MRS2500, 2-iodo-N ${ }^{6}$-methyl-(N)-methanocarba-2'-deoxyadenosine $3^{\prime}, 5^{\prime}$-bisphosphate; MRS2567, 1,2-di-(4-isothiocyanatophenyl)ethane; MRS2603, pyridoxal-5'-phosphate-6-azo-(4-chloro-3-nitrophenyl)-2,4-disulphonate; PPADS, pyridoxalphosphate-6-azophenyl-2', $4^{\prime}$-disulfonic acid. 
human $\mathrm{P}_{2} \mathrm{Y}_{11}$ is potently activated by adenosine triphosphate nucleotides, the canine orthologue displayed more selectivity towards the corresponding diphosphates. In this case, the nucleotide selectivity is due to differences in the amino acid sequence at the juxtaposition of TM6 and the third extracellular loop also reported to play an important role in agonist selectivity and signalling of other $\mathrm{G}$ protein-coupled receptors (GPCR) (Qi et al. [15]; Lawson and Wheatley [16]).

Despite their chemical stability, extracellular nucleotides are metabolised by several ecto-enzymes (Claes and Slegers [17]; Czajkowski and Baranska [18]; Goding et al. [19]; Zimmerman [20]). Extracellular hydrolysis complicates the evaluation of nucleotide-mediated effects on different cell types and can be overcome by the use of specific non-hydrolysable receptor agonists or ecto-enzyme inhibitors. Some $\mathrm{P} 2 \mathrm{Y}$ receptor antagonists, such as pyridoxalphosphate6-azophenyl-2',4'-disulfonic acid (PPADS), suramin, reactive blue 2 and 4,4'-diisothiocyanatostilbene-2,2' disulphonic acid (DIDS), are inhibitors of nucleotide hydrolyzing enzymes and are often used in studies of nucleotide-mediated signalling (Grobben et al. [21]). Nevertheless, care must be taken for the interpretation of experimental data since it is also shown that cells can internalise some of these molecules (Claes et al., [22]). Therefore specific P2Y receptor antagonists, developed for therapeutical purposes, have to be used to overcome the lack of specificity (Boeynaems et al. [23]; Lambrecht et al. [24]; Kam and Nethery [25]; Kim et al. [26]; Xu et al. [27]).

\section{$\mathrm{P} 2 \mathrm{Y}$ receptor expression on rat $\mathrm{C} 6$ glioma cells}

Rat C6 glioma is a tumoral cell line of glial origin with oligodendrocytic, astrocytic and neuronal progenitor properties. Due to a point mutation in 'phosphatase and tensin homologue deleted on chromosome ten' (PTEN), the phosphatidylinositol 3-kinase (PI 3-K)/ PKB signalling pathway is constitutively active and contributes to the proliferative and invasive properties of these cells (Kubiatowski et al. [28]; Roymans and Slegers [29]; Grobben et al. [30]). In addition, cell proliferation is sustained by secreted growth factors that stimulate growth factor receptors present on these cells. Such autocrine mechanisms are reported for IGFR, bFGFR and PDGFR (Okumura et al. [31]; Resnicoff et al. [32]; Strawn et al. [33]).

In C6 cells, an increase in cAMP by stimulation of the $\beta$-adrenergic receptor ( $\beta$-AR) or by addition of membrane permeable cAMP analogues, e.g., dibutyryl
cAMP (dBcAMP) or 8-chloro-cAMP, induces differentiation into an astrocyte type II (Roymans et al. [34]). During this process, cessation of cell growth is accompanied by a shift in intermediate filament synthesis from vimentin to glial fibrillary acidic protein (GFAP) (Backhovens et al. [35]). The latter protein is an astrocytic differentiation marker whose expression is regulated by cAMP at the transcriptional and translational level (Messens and Slegers [36]).

In our laboratory, the signalling pathways activated by extracellular nucleotides, and in particular those affecting cell proliferation and differentiation of $\mathrm{C} 6$ cells, were studied in detail. The presence of a P2Y receptor on these cells that negatively affects adenylate cyclase (AC) was postulated for more than a decade (Pianet et al. [37]; Boyer et al. [38]). This receptor is coupled to a $G_{i}$ protein and has been denominated P2 $\mathrm{Y}_{\mathrm{AC}^{-}}$(Claes et al. [39]; Grobben et al. [40]) before its identification as the $\mathrm{P}_{2} \mathrm{Y}_{12}$ receptor initially cloned from blood platelets (Czajkowski et al. [41]; Hollopeter et al. [11]; Jin et al. [42]). C6 cells also express the phospholipase (PL)C 3 -coupled $\mathrm{P}_{2} \mathrm{Y}_{1}, \mathrm{P}_{2} \mathrm{Y}_{2}$, $\mathrm{P}_{2} \mathrm{Y}_{4}$ and $\mathrm{P}_{2} \mathrm{Y}_{6}$ receptors (Czajkowski et al. [41]; Nicholas et al. [43]; Tu et al. [44]; Claes and Slegers [17]). Recently, we also demonstrated the presence of $\mathrm{P}_{2} \mathrm{Y}_{13}$ mRNA (Van Kolen and Slegers [45]) implicating the expression of three ADP-activated receptors in these cells, i.e., $\mathrm{P}_{2} \mathrm{Y}_{1}$, $\mathrm{P}_{2} \mathrm{Y}_{12}$ and $\mathrm{P}_{2} \mathrm{Y}_{13}$. Although 2MeSADP is reported as a potent $\mathrm{P} 2 \mathrm{Y}_{1}, \mathrm{P}_{2} \mathrm{Y}_{12}$ and $\mathrm{P} 2 \mathrm{Y}_{13}$ agonist, stimulation with this compound inhibits $\mathrm{AC}$, but induces no significant activation of PLC, indicating that the $\mathrm{P}_{2} \mathrm{Y}_{1}$ receptor is not activated by ADP in cells grown in chemically defined medium (Grobben et al. [40]). This is confirmed by Czajkowski et al. [46], who showed that, in cells cultivated in the presence of fetal calf serum, ADP signalling is predominantly determined by the $\mathrm{P}_{2} \mathrm{Y}_{1}$ receptor. However, upon serum deprivation, expression of the $\mathrm{P}_{2} \mathrm{Y}_{1}$ receptor is decreased and the $\mathrm{P}_{2} \mathrm{Y}_{12}$ receptor becomes the main activated receptor. Characterization of $\mathrm{P}_{2} \mathrm{Y}_{13}$ receptor function is complicated by the fact that $\mathrm{P} 2 \mathrm{Y}_{12}$ and $\mathrm{P} 2 \mathrm{Y}_{13}$ receptors have almost the same agonist profile (Table 1). The receptor antagonist $\mathrm{N}^{6}$-(2-methylthioethyl)-2-(3,3,3-trifluoropropylthio)- $\beta, \gamma$-dichloromethylene ATP (AR-C69931MX), often used as a specific $\mathrm{P}_{2} \mathrm{Y}_{12}$ antagonist, also blocks the $\mathrm{P}_{2} \mathrm{Y}_{13}$ receptor (Marteau et al. [47]). While the human and mouse $\mathrm{P} 2 \mathrm{Y}_{13}$ receptor, like the $\mathrm{P} 2 \mathrm{Y}_{12}$, is more potently activated by $2 \mathrm{MeSADP}$ than $\mathrm{ADP}$, the rat $\mathrm{P}_{2} \mathrm{Y}_{13}$ receptor shows a higher selectivity for ADP (Fumagalli et al. [48]). In C6 cells, further distinction between the signalling of $\mathrm{P}_{2} \mathrm{Y}_{12}$ and $\mathrm{P}_{2} \mathrm{Y}_{13}$ receptors can be made by the use of PPADS, a $\mathrm{P}_{2} \mathrm{Y}_{13}$ antagonist without effect on $\mathrm{P}_{2} \mathrm{Y}_{12}$, and $\mathrm{P}^{1}, \mathrm{P}^{4}$ di(adenosine-5') tetraphosphate $\left(\mathrm{Ap}_{4} \mathrm{~A}\right)$, a $\mathrm{P}_{2} \mathrm{Y}_{13}$ antagonist that stimulates the $\mathrm{P}_{2} \mathrm{Y}_{12}$ receptor (Claes et al. [39]; 
Grobben et al. [40]; Marteau et al. [47]). In addition, recently synthesised PPADS derivatives pyridoxal-5'phosphate-6-azo-(2-chloro-5-nitrophenyl)-2,4-disulphonate (MRS2211) and pyridoxal-5'-phosphate-6-azo-(4-chloro-3nitrophenyl)-2,4-disulphonate (MRS2603) have no effect on the $\mathrm{P}_{2} \mathrm{Y}_{12}$ receptor but antagonise the $\mathrm{P}_{2} \mathrm{Y}_{13}$ receptor (Kim et al. [26]).

Although P2Y receptor expression in C6 cells depends on the cultivation conditions (Czajkowski et al. [46]), unpublished data of our laboratory revealed that induction of differentiation into astrocytes type II by dbcAMP $(1 \mathrm{mM})$ - or (-)-isoproterenol $(5 \mu \mathrm{M})$ does not significantly alter the expression of $\mathrm{P} 2 \mathrm{Y}$ receptors. These observations are in accordance with previous studies on the expression of $\mathrm{P}_{2} \mathrm{Y}_{1}, \mathrm{P}_{2} \mathrm{Y}_{2}, \mathrm{P}_{2} \mathrm{Y}_{4}, \mathrm{P}_{2} \mathrm{Y}_{6}$, $\mathrm{P}_{2} \mathrm{Y}_{12}, \mathrm{P}_{2} \mathrm{Y}_{13}$ and $\mathrm{P} 2 \mathrm{Y}_{14}$ receptors in glial cells and primary astrocytes (Bianco et al. [49]; Fumagalli et al. [48, 50]; Sasaki et al. [51]). The function of P2Y receptor expression in glial cells is still under investigation, but a number of studies point to an important role in the intercellular communication between astrocytes and neurons (Bezzi and Volterra, [52]). Another well documented effect of extracellular ATP is induction of reactive astrogliosis upon activation of ERK and cyclooxygenase (COX)-2 (Brambilla et al. [53]).

Similar to the observations made in C6 cells, functional responses of $\mathrm{P} 2 \mathrm{Y}$ receptor subtypes in microglial cells depend on cultivation conditions. In N9 mouse brain microglia stimulation of expressed P2Y receptors induces $\mathrm{Ca}^{2+}$ mobilization but only $\mathrm{P}_{2} \mathrm{Y}_{6}$ and $\mathrm{P}_{2} \mathrm{Y}_{14}$ receptor-mediated responses are increased upon activation of microglia with lipopolysaccharide. The enhanced $\mathrm{P}_{2} \mathrm{Y}_{6}$ response is correlated with mRNA increase which was not the case for the $\mathrm{P}_{2} \mathrm{Y}_{14}$ receptor-mediated $\mathrm{Ca}^{2+}$ mobilization (Bianco et al. [49]). Furthermore, stimulation of microglial P2 $\mathrm{Y}_{12 / 13}$ receptors induces membrane ruffling and chemotaxis towards injured neurons through $\mathrm{G}_{\mathrm{i} / \mathrm{o}}$ protein-mediated activation of Rac (Honda et al. [54]). The observations made in astrocytes and microglial cells emphasise the importance of $\mathrm{P} 2 \mathrm{Y}$ receptors in brain signalling and identify these receptors as putative targets in defective neurotransmission, neuroimmune functioning, cell survival and cell proliferation in response to oxidative stress and brain injury.

\section{P2Y receptor-activated signalling cascades}

Second messengers

P2Y receptors are generally linked to PLC activation that catalyses the rapid hydrolysis of phosphatidylino- sitol 4,5-bisphosphate into the intracellular messenger inositol 1,4,5-triphosphate $\left(\mathrm{IP}_{3}\right)$ and diacylglycerol (DAG). Activation of PLC occurs by $\mathrm{G}_{i} \alpha-$ and/or $\mathrm{G}_{\mathrm{q}} \alpha$-dependent mechanisms (Communi et al. [55]). Besides signalling through $\mathrm{G} \alpha$ subunits, intracellular $\mathrm{Ca}^{2+}$ concentration is also affected by $\mathrm{G} \beta \gamma$ subunitdependent interaction with voltage-gated $\mathrm{Ca}^{2+}$ channels. Several reports indicated modulation of $\mathrm{K}^{+}$ currents and PLC $\beta$ activation induced by distinct domains of $\mathrm{G} \beta \gamma$ (Mirshahi et al. [56]). Co-expression studies performed in rat sympathetic neurons demonstrated that $\mathrm{P} 2 \mathrm{Y}_{1}, \mathrm{P} 2 \mathrm{Y}_{2}$ and $\mathrm{P} 2 \mathrm{Y}_{6}$ receptors trigger the closing of $\mathrm{N}$-type $\mathrm{Ca}^{2+}$ and $\mathrm{M}$-type $\mathrm{K}^{+}$channels, whereas $\mathrm{P}^{2} \mathrm{Y}_{4}$ receptor stimulation also displayed coupling to M-type $\mathrm{K}^{+}$channels producing a less efficient inhibition of $\mathrm{Ca}^{2+}$ currents. In rat brain capillary endothelial cells, it was shown that the $\mathrm{P}_{2} \mathrm{Y}_{12}$ receptor inhibits $\mathrm{I}_{\mathrm{Ca}(\mathrm{N})}$ and activates a $\mathrm{G}$ proteincoupled inward rectifier $\mathrm{K}^{+}$(GIRK) channel. Interestingly, stimulation of the $\mathrm{P}_{2} \mathrm{Y}_{1}$ receptor also induces a $\mathrm{K}^{+}$current that is rapidly followed by inactivation. Inhibition of $\mathrm{I}_{\mathrm{Ca}(\mathrm{N})}$ by $\mathrm{P}_{2} \mathrm{Y}_{12}$ receptor stimulation is also reported in PC12 cells while in HEK 293 this inhibition is mediated by the $\mathrm{P}_{2} \mathrm{Y}_{13}$ receptor (Filippov et al. [57-60]; Simon et al. [61]; Wirkner et al. [62]). From co-expression studies of P2Y receptors with GIRK1 or GIRK2 in rat sympathetic neurons, it was concluded that $\mathrm{P} 2 \mathrm{Y}$ receptors activate GIRK channels by the $\beta \gamma$ subunits of $\mathrm{G}_{\mathrm{i} / \mathrm{o}}$ and inhibit these channels by the $\alpha$ subunits of $\mathrm{G}_{\mathrm{q}}$ (Filippov et al. [63]).

$\mathrm{P} 2 \mathrm{Y}$-induced calcium release is followed by opening of voltage-independent $\mathrm{Ca}^{2+}$ channels. Although this response is observed in a variety of cell types, the physiological implications are miscellaneous. In this context, it has been reported that extracellular ATP induces a $\mathrm{Ca}^{2+}$ wave that propagates through neighbouring astrocytes by GAP junctions (Suadicani et al. [64]). In situations of increased neuronal activity or cell damage, ATP stimulates a $\mathrm{Ca}^{2+}$-dependent protonefflux from astrocytes. Acidification of the extracellular environment serves as a negative feedback mechanism for neurotransmitter release, but also increases blood flow by vasodilatation in cerebral arterioles (Dienel and Hertz [65]; Dixon et al. [66]). Although $\mathrm{Ca}^{2+}$ signalling is observed in a variety of cell types, the time dependence of the response is cell type specific. This is especially the case for the $\mathrm{P}_{2} \mathrm{Y}_{1}$ receptor which triggers persistent or transient $\mathrm{Ca}^{2+}$ responses when it is expressed in human 1321N1 astrocytoma or C6 glioma cells, respectively (Czajkowski et al. [41]; Sellers et al. [67]). A recent study also revealed that, in glial cells, prolongation of the $\mathrm{P}_{2} \mathrm{Y}_{1}$ receptor-induced $\mathrm{Ca}^{2+}$ response is regulated by interaction with the $\mathrm{Na}^{+} / \mathrm{H}^{+}$ 
exchanger regulatory factor type-2 which determines the signalling pathways that are ultimately activated in different cell types (Fam et al. [68]). Indeed, while transient $\mathrm{P}_{2} \mathrm{Y}_{1}$ receptor signalling increases proliferation in $\mathrm{C} 6$ cells, sustained signalling triggers apoptotic cascades in 1321N1 astrocytoma cells (Czajkowski et al. [46]; Sellers et al. [67]).

A well-known response to PLC-generated DAG and $\mathrm{IP}_{3} / \mathrm{Ca}^{2+}$ is the activation of classical PKCs that are involved in rapid internalisation and desensitisation of GPCRs through phosphorylation of residues localised in their cytoplasmic tail. In this regard, PKC $\beta I$ is reported to attenuate phosphatidylinositol (PI)-hydrolysis induced by $\mathrm{P} 2 \mathrm{Y}_{1}$ and $\mathrm{P} 2 \mathrm{Y}_{2}$ receptors in endothelial cells (Chen and Lin [69]). In astrocytes, high frequency stimulation of the $\mathrm{P}_{2} \mathrm{Y}_{1}$ receptor by repeated addition of ATP causes rapid suppression of the $\mathrm{P}_{2} \mathrm{Y}_{1}$ receptorinduced $\mathrm{Ca}^{2+}$ response. This phenomenon, observed as $\mathrm{Ca}^{2+}$ oscillations, is mediated by protein kinase Cdependent phosphorylation of Thr339 in the carboxyterminus of the $\mathrm{P}_{2} \mathrm{Y}_{1}$ receptor (Fam et al. [70]). Besides modulation of receptor responsiveness, PKC signalling also affects long term effects. In the human osteoblastic HOBIT cell line, ATP increases expression of the early growth response protein- 1 by a mechanism that requires a $\mathrm{Ca}^{2+}$-independent PKC isoform (Pines et al. [71]). In vascular smooth muscle cells, UDP stimulates cell cycle progression by a PLC- and $\mathrm{PKC} \delta$-dependent cascade (Hou et al. [72]). The same isoform is involved in ATPmediated mitogenic signalling in astrocytes, but in these cells PKC $\delta$ activation does not involve PLC but requires PLD-dependent choline formation (Neary et al. [73]).

In addition to PLC-coupled receptors, a growing number of $\mathrm{P} 2 \mathrm{Y}$ receptors have been shown to affect the activity of AC. Besides the existence of indirect mechanisms linked to an increase in cAMP (discussed in Communi et al. [55]), only the $\mathrm{P}_{2} \mathrm{Y}_{11}$ receptor is directly coupled to activation of AC and PLC while $\mathrm{P}_{2} \mathrm{Y}_{12}, \mathrm{P}_{2} \mathrm{Y}_{13}$ and $\mathrm{P} 2 \mathrm{Y}_{14}$ receptors negatively affect cAMP synthesis (Chambers et al. [13]; Communi et al. [10]; Hollopeter et al. [11]; Zhang et al. [12]). Adenylate cyclase-dependent signalling is often mediated by the cAMP-regulated kinase PKA. Stimulation of the $\mathrm{P}_{2} \mathrm{Y}_{11}$ receptor with ATP is shown to activate human monocyte-derived dendritic cells by increased cAMP/PKA signalling (Wilkin et al. [74]). In bovine adrenocortical fasciculate cells, ADP and ATP increase cortisol production through PKA activation by an as yet unidentified $\mathrm{G}_{\mathrm{s}}$ protein-coupled $\mathrm{P} 2 \mathrm{Y}$ receptor (Nishi et al. [75]). Although in unstimulated cells the cytosolic cAMP concentration is already low, its further decrease by $G_{i}$ protein-coupled re- ceptors is sometimes sufficient to exert a significant inhibitory action towards PKA. Such a response is reported in microglial cells where ATP and ADP binding to $\mathrm{P} 2 \mathrm{Y}_{12 / 13}$ receptors mediate chemotaxis by PKA-dependent translocation of $\beta 1$ integrins to ruffling regions of the cell (Nasu-Tada et al. [76]).

Despite the fact that cells express a myriad of different GPCRs and downstream acting regulators, receptor stimulation promotes rapid and specific responses. In addition, multiple GPCRs, sharing the same second messenger cascade, can induce different cellular events in one cell type indicating that GPCR signal propagation requires physical interactions in a defined cellular compartment. An example of spatial organised signalling is the $\beta$-arrestin-dependent targeting of an activated receptor into clathrin-coated vesicles or enrichment in membrane microdomains (lipid rafts) formed by cholesterol and sphingolipids (Anderson [77]; DeFea et al. [78]). Modulation of receptor function by rafts is confirmed for an increasing number of GPCRs including P2Y receptors (Anderson [77]; Ostrom and Insel [79]). In endothelial cells, it is reported that $\mathrm{P} 2 \mathrm{Y}$ receptor-induced vasodilatation is abolished by disruption of caveolae with methyl- $\beta$ cyclodextrin (Kaiser et al. [80]). In C6 glioma cells, signalling by $\mathrm{P}_{2} \mathrm{Y}_{2}$ and 5-hydroxytryptamine $(\mathrm{HT})_{2 \mathrm{~A}}$ receptors is attenuated after knock-down of caveolin-1 by si-RNA. Moreover, interaction between the $5-\mathrm{HT}_{2 \mathrm{~A}}$ receptor and caveolin-1 facilitates its interaction with $\mathrm{G} \alpha_{\mathrm{q}}$. Since $\mathrm{P} 2 \mathrm{Y}_{2}$ receptor mRNA is downregulated by caveolin-1 knock-down, further studies are required to demonstrate localisation of $\mathrm{P}_{2} \mathrm{Y}_{2}$ receptors in caveolae of C6 cells (Bhatnagar et al. [81]).

\section{Small GTPases as molecular switches}

The processing of extracellular stimuli by GPCRs often involves signalling by second messengers (cAMP, DAG, $\mathrm{Ca}^{2+}$ ) towards small GTPases and/or cross-talk with tyrosine kinases. $\mathrm{G}_{\mathrm{q}}$ protein-coupled receptor signalling via PLC $\beta$ induces formation of DAG and $\mathrm{IP}_{3}, \mathrm{Ca}^{2+}$ mobilisation and activation of PKC ultimately leading to activation of proline-rich tyrosine kinase 2 (Pyk2). Pyk2 cooperates with Src to recruite Grb2 and SOS, a guanine nucleotide exchange factor (GEF) that activates Ras (Lev et al. [82]). Such a mechanism is reported for Ras-dependent ERK activation induced by the protease-activated receptor- 1 in astrocytes (Wang and Reiser [83]). In PC12 cells, stimulation of the $\mathrm{P}_{2} \mathrm{Y}_{2}$ receptor also triggers tyrosine phosphorylation of Pyk2, but further signalling to Ras involves EGFR transactivation by Src (Soltoff et al. 
[84]). Tyrosine kinase-dependent Ras signalling is also reported for $G_{i}$ protein-coupled receptors, but this proceeds through $G \beta \gamma$ subunit-mediated activation of PI 3-K $\gamma$ and Shc (Ellis et al. [85]; Lopez-Ilasaca et al. [86]).

GEFs can also be regulated in a tyrosine kinaseindependent manner that proceeds through direct activation by cAMP, DAG and $\mathrm{Ca}^{2+}$ or by interaction with $G \alpha$ subunits as observed for the $G_{\mathrm{q} / 11}$ proteinmediated activation of RhoA (Bhattacharya et al. [87]; Bos [88]; Lutz et al. [89]; Walker et al. [90]).

$\mathrm{P} 2 \mathrm{Y}$ receptor signalling towards GTPases is involved in short term responses, such as stress fibre formation or modulation of cell adhesion, but also in long term responses like cell proliferation. Mitogenic Ras-dependent P2Y responses are reported for C6 and HEK293 cells where Ras is implicated in $\mathrm{P}_{2} \mathrm{Y}_{2}$ receptor-dependent signalling to the ERK pathway (Gao et al. [91]; $\mathrm{Tu}$ et al. [44]). On the other hand, increased proliferation of $\mathrm{C} 6$ cells by the $\mathrm{P}_{2} \mathrm{Y}_{12}$ receptor proceeds independently of Ras, but requires RhoA-dependent activation of ERK and Rho-associated coiled-coilcontaining protein kinase (ROCK) (Grobben et al. [40]; Van Kolen and Slegers, unpublished data). Interestingly, when the $\mathrm{P}_{2} \mathrm{Y}_{12}$ receptor is expressed in $\mathrm{CHO}$ cells it activates ERK and RhoA/ROCK by independent mechanisms (Soulet et al. [92]).

Another example of cross-talk between $\mathrm{P} 2 \mathrm{Y}$ receptors and GTPases is observed in blood platelets. As mentioned above, release of ADP and subsequent $\mathrm{P}_{2} \mathrm{Y}_{1}$ and $\mathrm{P}_{2} \mathrm{Y}_{12}$ receptor binding is essential for collageninduced platelet aggregation. A crucial step for immediate and sustained aggregation of platelets is the activation of Rap1 that increases the affinity between integrin $\alpha_{\mathrm{IIb}} \beta_{3}$ and fibrinogen. Knock-out studies revealed that ADP-induced GTP loading of Rap1 proceeds through both $G_{i}$ and $G_{q}$ signalling by $P 2 Y_{12}$ and $\mathrm{P}_{2} \mathrm{Y}_{1}$ receptors, respectively. The mechanism initiated by the $\mathrm{P}_{2} \mathrm{Y}_{12}$ receptor is shown to be PI 3$\mathrm{K}$-dependent while $\mathrm{P} 2 \mathrm{Y}_{1}$-mediated activation of Rap1 requires $\mathrm{Ca}^{2+}$ mobilisation (Woulfe et al. [93]; Greco et al. [94]; Larson et al. [95]; Lova et al. [96, 97]). Stimulation of the $\mathrm{P}_{2} \mathrm{Y}_{1}$ receptor also contributes to platelet shape changes by a $\mathrm{Ca}^{2+}$-independent pathway. RhoA and its effector ROCK are activated by ADP through $\mathrm{G}_{12 / 13}$ protein-dependent signalling of the $\mathrm{P}_{2} \mathrm{Y}_{1}$ receptor and contribute to rapid actin polymerization and shape changes (Paul et al. [98]). Signalling towards Rho GTPases is also important in other systems. In brain, ATP and ADP induce membrane ruffling and chemotaxis of microglial cells through $G_{i}$ protein-dependent activation of Rac upon stimulation of $\mathrm{P}_{2} \mathrm{Y}_{12 / 13}$ receptors (Sasaki et al. [51];
Honda et al. [54]). Stress fibre formation in vascular smooth muscle cells is reported to be mediated by RhoA/ROCK signalling that becomes activated upon stimulation of $\mathrm{P}_{2} \mathrm{Y}_{1}, \mathrm{P}_{2} \mathrm{Y}_{2}, \mathrm{P}_{2} \mathrm{Y}_{4}$ and $\mathrm{P}_{2} \mathrm{Y}_{6}$ receptors (Sauzeau et al. [99]). In the latter study, information concerning the signalling towards RhoA is lacking. In a more recent study on endothelial cells, transactivation of VEGFR upon $\mathrm{P}_{2} \mathrm{Y}_{2}$ receptor stimulation and recruitment of the RhoGEF Vav is shown to be a possible mechanism to initiate RhoA-mediated cell adhesion (Seye et al. [100]).

Although several P2Y receptors activate RhoA, downstream signalling and physiological consequences are determined by celltype specific mechanisms leading to diverse responses.

\section{ERK signalling}

Several GPCRs are coupled to enhanced proliferation by multiple signal transduction pathways that phosphorylate ERK. Activation of this kinase requires Ras or GTPases of the RhoA family and is often modulated by second messenger-activated pathways, although cross-talk with growth factor receptors also triggers ERK signalling.

In neurons $\mathrm{G}_{\mathrm{s}}$ protein-mediated activation of $\mathrm{AC}$ increases ERK phosphorylation by a PKA/Rap1/BRaf cascade. In contrast, induction of cAMP synthesis decreases ERK phosphorylation in C6 cells and astrocytes by a negative action of PKA on the Ras/cRaf1 interaction, or by Rap1-mediated inhibition of cRaf1. These observations led to the hypothesis that an increase in cAMP stimulates MEK/ERK signalling in B-Raf expressing cells but inhibits this cascade in BRaf negative cells (Dugan et al. [101]). In both cases, PKA activation has a central role and mediates its effects through Src and Rap1 activation (Stork and Schmitt [102]). Although the majority of cAMPdependent effects can be explained by this hypothesis, a few exceptions are reported. In some B-Raf positive cells, an increase in cAMP is shown to inhibit B-Raf, suggesting that regulation of this kinase by cAMP also depends on other cell type specific factors. One model suggests the involvement of 14-3-3 proteins acting as scaffolding proteins to shield B-Raf and Raf1 from PKA phosphorylation (Qiu et al. [103]). Other studies indicated that regulation of ERK by cAMP involves multiple cell type specific mechanisms. In COS cells overexpressing $\beta$-AR1 or $\beta$-AR2, stimulation of these receptors activate $A C$ through a $\mathrm{G}_{\mathrm{s}}$ protein-dependent mechanism as expected. However, PKA also phosphorylates these receptors and induces a switch from $\mathrm{G}_{\mathrm{s}}$ to $\mathrm{G}_{\mathrm{i} / \mathrm{o}}$ protein binding to $\beta$-AR resulting in 
activation of ERK upon receptor stimulation (Martin et al. [104]). Modulation of the ERK cascade by cAMP can also occur independently of PKA. In this context, cAMP binds Epac1 or Epac2, "exchange protein directly activated by cAMP," GEFs that activate Rap1 and Rap2 (de Rooij et al. [105, 106]; Kawasaki et al. [107]). Several examples of $\mathrm{G}_{\mathrm{s}}$ protein-mediated activation of ERK through Epac are reported (Laroche-Joubert et al. [108]; Lin et al. [109]). Another PKA-independent mechanism of ERK phosphorylation is the $\mathrm{G}_{\mathrm{s}} \beta \gamma /$ Src-mediated activation of Ras (Schmitt and Stork [110]).

$\mathrm{G}_{\mathrm{q}}$ and some $\mathrm{G}_{\mathrm{i} / \mathrm{o}}$ protein-coupled receptors activate PLC $\beta$ and trigger formation of $\mathrm{IP}_{3}$ and $\mathrm{DAG}$, resulting in $\mathrm{Ca}^{2+}$ release and PKC activation, respectively. $\mathrm{Ca}^{2+}$ increase can activate ERK through Pyk2 that activates Ras as mentioned above. Otherwise, $\mathrm{Ca}^{2+}$-dependent modulation of Ras activity is also mediated by Ras guanine nucleotide-releasing factor (RasGRF), a GEF that contains $\mathrm{Ca}^{2+}$ - and DAG-binding domains, (Ebinu et al. [111]) or by $\mathrm{Ca}^{2+} /$ calmodulin-dependent kinases CaMK-II and CaMK-IV (reviewed in Agell et al. [112] and Walker et al. [90]). Increase of intracellular calcium and DAG formation also results in activation of cPKCs while DAG formation alone is sufficient to activate nPKCs. Increase in PKC activity modulates the ERK cascade through Ras by inhibition of RasGAPs and/or stimulation of RasGEFs. In addition, PKC can activate Raf independently of Ras. Indeed, it is shown that PKC $\alpha$ phosphorylates Raf at Ser499 (Kolch et al. [113]). However, mutation of this serine residue into alanine does not affect Raf activity in response to phorbol esters (Yip-Schneider et al. [114]). More convincing data were obtained when constitutively active PKC was expressed in rat 6 fibroblasts. These cells display Ras-independent signalling towards ERK by direct phosphorylation of Raf by $\mathrm{PKC} \varepsilon$. Since activation of Ras is required in several systems this interaction is cell type-dependent (Cacace et al. [115]; Ueffing et al. [116]). Direct phosphorylation of Raf by PKC is also involved in ERK activation by the $\mathrm{G}_{\mathrm{i}}$ protein-coupled leukotriene $(\mathrm{LT}) \mathrm{D}_{4}$ receptor in intestinal epithelial cells. Although stimulation of this receptor also triggers a parallel PKC-independent activation of Ras, transfection experiments confirmed that Ras is dispensable for $\mathrm{LTD}_{4}$ receptor-mediated ERK activation (Paruchuri et al. [117]). When constitutive active point mutants of $\mathrm{PKC} \alpha, \mathrm{PKC} \delta$ and $\mathrm{PKC} \varepsilon$ were introduced in COS cells, only $\mathrm{PKC} \delta$ activated the ERK cascade (Ueda et al. [118]), indicating that involvement of PKC isoforms in ERK signalling vary among different cell types. This is also confirmed by the observation that, in platelets, cPKCs are involved in thrombin-induced MEK and ERK activation independently of Ras or Raf (Nadal-Wollbold et al. [119]).

$\mathrm{G}_{\mathrm{i} / \mathrm{o}}$ protein-coupled receptors that are not linked to PLC activation can also modulate mitogenic signalling through G $\beta \gamma$-dependent activation of PI 3-K $\gamma$. Signalling from PI 3-K $\gamma$ to ERK proceeds through Shc/Grb2/ SOS/Ras (Lopez-Ilasaca et al. [86]). An increasing number of reports point to the involvement of $\mathrm{PKC} \zeta$ in $\mathrm{G}_{\mathrm{i}}$ protein-dependent phosphorylation of ERK. The first observation was made in $\mathrm{CHO}$ cells where stimulation of the LPA receptor triggers MEK/ERK signalling via a PI 3-K $\gamma$-dependent activation of $\mathrm{PKC} \zeta$ not abrogated by transfection with dominant negative Ras (Takeda et al. [120]). In addition, a recent report indicated that angiotensin II-induced ERK activation in rat vascular smooth muscle cells requires interaction

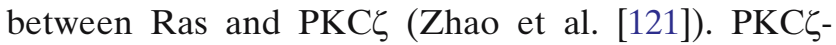
dependent activation of ERK is mediated by interaction with MEK, a property shared by other PKC isoforms (Schönwasser et al. [122]), or by regulation of Raf1. Studies performed in rat embryonic hippocampal cells indicated that $\mathrm{PKC} \zeta$ can phosphorylate the Raf kinase inhibitory protein (RKIP) resulting in dissociation of the Raf1/RKIP complex (Corbit et al. [123]). In addition, co-immunoprecipitation experiments in COS cells showed that modulation of c-Raf1 by $\mathrm{PKC} \zeta$ is also regulated by 14-3-3 scaffolding proteins (Van Der Hoeven et al. [124]).

Initial studies concerning $\mathrm{P} 2 \mathrm{Y}$ receptor-mediated activation of ERK were made in astrocytes where this cascade was shown to be involved in cell proliferation and process elongation (Neary and Zhu [125]; King et al. [126]).

Although ATP triggers pertussis toxin insensitive $\mathrm{IP}_{3}$ and $\mathrm{Ca}^{2+}$ responses in astrocytes, these are not required for the signalling towards ERK which depends on rapid membrane translocation of $\mathrm{PKC} \delta$ upon phosphatidylcholine hydrolysis by PLD (Neary et al. [73]). In PC12 cells, stimulation of the $\mathrm{P}_{2} \mathrm{Y}_{2}$ receptor also induces PKC $\delta$-dependent ERK phosphorylation, although this mechanism requires $\mathrm{Ca}^{2+}$ and Pyk2 for the association of Shc and Grb2 to the receptor and for subsequent activation of SOS/Ras/ Raf/MEK/ERK (Soltoff et al. [84]). Many reports showed that $\mathrm{P} 2 \mathrm{Y}$ receptor-mediated ERK signalling requires PKC activation (Graham et al. [127]; Huwiler and Pfeilschifter [128]; Erlinge [129]), but a PKCindependent mechanism is reported in thyroid FRTL5 cells (Tornquist et al. [130]). In 1321N1 astrocytoma cells, stimulation of the $\mathrm{P}_{2} \mathrm{Y}_{6}$ receptor with UDP activates $\mathrm{PKC} \alpha, \varepsilon$ and $\zeta$ which are correlated with ERK phosphorylation (Kim et al. [131]). Although the use of general PKC inhibitors 3-[1-(dimethylaminopropyl) 
indol-3-yl]-4-(indol-3-yl)maleimide hydrochloride (GF109203X) and 12-(2-cyanoethyl)-6,7,12,13-tetrahydro-13-methyl-5-oxo-5H-indolo(2,3-a)pyrrolo(3,4-c)carbazole (Gö 6976) diminished ERK signalling, the lack of specificity of these compounds makes it difficult to determine the contribution of each of these $\mathrm{PKC}$ isoforms in the mechanism of ERK activation (Way et al. [132]).

Enhanced proliferation by a $\mathrm{P} 2 \mathrm{Y}$ receptor-mediated stimulation of the ERK pathway has been reported in a large number of cell types such as human mesangial cells, vascular smooth muscle cells and primary astrocytes (Huwiler and Pfeilschifter [128]; Harper et al. [133]). Transient ERK activation by $\mathrm{P}_{2} \mathrm{Y}_{1}, \mathrm{P}_{2} \mathrm{Y}_{2}$ or $\mathrm{P}_{2} \mathrm{Y}_{12}$ receptor stimulation also increases cell proliferation in C6 cells indicating that activation of several P2Y receptor subtypes can converge into the same physiological response (Table 2) (Tu et al. [44]; Claes et al. [39]; Czajkowski et al. [46]).

In addition to mitogenesis, $\mathrm{P} 2 \mathrm{Y}$ receptor signalling towards ERK elicits other physiological processes including cell survival, inflammation and reactive gliosis. In human lung microvascular endothelial cells, hyperoxia-induced release of ATP results in cell survival through ERK and PI 3-K signalling cascades activated by $\mathrm{P} 2 \mathrm{Y}_{2}$ and/or $\mathrm{P}_{2} \mathrm{Y}_{6}$ receptors, while stimulation of the ERK cascade by the $\mathrm{P}_{2} \mathrm{Y}_{6}$ receptor protects $1321 \mathrm{~N} 1$ astrocytoma cells from $\mathrm{TNF} \alpha$-induced apoptosis (Ahmad et al. [134]; Kim et al. [131]). Rapid ERK1/2 and p38 MAPK activation plays an important role in $\mathrm{P}_{2} \mathrm{Y}_{2}$ receptor-dependent primary granule release from human neutrophils (Meshki et al. [135]). A similar phenomenon is observed in articular chondrocytes where ATP acts as a pro-inflammatory mediator by increasing arachidonic acid production and release of prostaglandin $\mathrm{E}_{2}$ through a $\mathrm{P}_{2} \mathrm{Y}_{2}$ receptor- dependent activation of p38 and ERK1/2 (Berenbaum et al. [136]). In primary astrocytes, P2Y receptormediated ERK activation by ATP is shown to induce reactive astrogliosis, a phenomenon that occurs upon brain injury and is characterised by astroglial proliferation, cellular hypertrophy and up regulation of GFAP. This effect is mediated by an ERK-dependent increase in the expression of COX-2 (Brambilla et al. [53]). In C6 cells, $\mathrm{P}_{2} \mathrm{Y}_{12}$ and $\mathrm{P} 2 \mathrm{Y}_{2}$ receptor-induced activation of ERK is coupled to an enhanced cell proliferation, while a negative modulation of GFAP synthesis by the $\mathrm{P}_{2} \mathrm{Y}_{12}$ receptor is reported (Claes et al. [39]; Tu et al. [44]; Van Kolen and Slegers [45]). These differences are probably due to the fact that in C6 cells induction of GFAP expression is not correlated with an enhanced proliferation but requires growth arrest.

In summary, most $\mathrm{P} 2 \mathrm{Y}$ receptors are coupled to ERK phosphorylation, but the signalling mechanism and the physiological effect of this pathway are cell type specific and are determined by the cellular context.

\section{PI 3-K/PKB signalling}

$\mathrm{PKB} / \mathrm{Akt}$ is involved in a large variety of cellular processes including glucose metabolism, mitogenesis, differentiation, survival and motility (Brazil et al. [137]). This member of the AGC protein kinase superfamily is recruited to the plasmamembrane upon PI 3-K-mediated PIP3 formation, but is also controlled in a PI 3-K-independent, but calmodulin-dependent, fashion upon intracellular $\mathrm{Ca}^{2+}$ mobilisation by stimulation of neuronal NMDA receptors (Cantley [138]; Leevers et al. [139]; Woodgett [140]; Yano et al. [141]).

Modulation of PKB activity is reported for a variety of GPCR ligands including adrenergics, cannabinoids,

Table 2 G protein-dependent modulation of ERK and PKB signalling cascades in C6 cells.

\begin{tabular}{|c|c|c|c|c|}
\hline & $\mathrm{G}$ protein & ERK & PI 3-K/PKB & Effect \\
\hline $\mathrm{P} 2 \mathrm{Y}_{1}$ & $\mathrm{G}_{\mathrm{q}}$ & $\uparrow$ PLC-PKC-Ca ${ }^{2+}$-Ras. & $\begin{array}{l}\downarrow \text { Attenuation of PI 3-K } \\
\text { activated by growth } \\
\text { factors }\end{array}$ & Proliferation \\
\hline $\mathrm{P} 2 \mathrm{Y}_{2}$ & $\mathrm{G}_{\mathrm{q}}$ & $\uparrow$ PLC-PKC-Ca ${ }^{2+}$-Ras. & - & Proliferation \\
\hline $\mathrm{P}_{2} \mathrm{Y}_{12}$ & $\mathrm{G}_{\mathrm{i}}$ & $\uparrow$ RhoA-PKC-Raf-MEK & $\uparrow \mathrm{PI} 3-\mathrm{K} / \mathrm{PKB}$ & $\begin{array}{l}\text { Proliferation/inhibition of } \\
\text { astrocytic differentiation }\end{array}$ \\
\hline$\mu \mathrm{OR}$ & $\mathrm{G}_{\mathrm{i}}$ & $\uparrow \mathrm{FGF}$ transactivation & - & Proliferation \\
\hline$\beta$-AR & $\mathrm{G}_{\mathrm{s}}$ & $\begin{array}{l}\downarrow \text { Transient inhibition } \\
\text { dependent on cAMP }\end{array}$ & $\begin{array}{l}\downarrow \text { Transient inhibition } \\
\text { by cAMP }\end{array}$ & $\begin{array}{l}\text { Growth arrest/astrocytic } \\
\text { differentiation }\end{array}$ \\
\hline $\mathrm{CB}$ & $\mathrm{G}_{\mathrm{s}}$ & $\downarrow$ Sustained inhibition & $\downarrow$ Sustained inhibition & Growth arrest/apoptosis \\
\hline
\end{tabular}

Transient ERK activation by $\mathrm{P}_{2} \mathrm{Y}_{1}$ (Czajkowski et al. [46]), $\mathrm{P} 2 \mathrm{Y}_{2}$

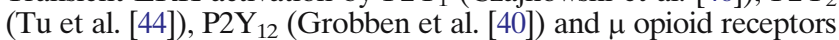
( $\mu$ OR) (Belcheva et al. [198]) enhances cell proliferation while stimulation of the $\beta$-adrenergic receptor $(\beta-A R)$ transiently inhibits ERK and PKB concomitant with induction of differentiation (Wang et al. [149]; Van Kolen and Slegers [45]). Inhibition of these pathways by cannabinoids $(\mathrm{CB})$ is sustained and induces apoptosis (Ellert- Miklaszewska et al. [184]). 
carbachol, glutamate, histamine, nucleotides and thrombin (Dickenson [142]; Franke et al. [143], Iacovelli et al. [144] Murga et al. [145]; Sanchez et al. [146]). Due to the existence of multiple phosphoinositide-dependent cascades, regulation of PKB signalling by GPCRs varies among the studied systems.

In HEK293 cells, stimulation of $\beta$-AR with (-)-isoproterenol activates PKB via $\mathrm{G}_{\mathrm{s}} \beta \gamma, \mathrm{Src}$, Ras and PI 3-K (Schmitt and Stork [110]; Bommakanti et al. [147]) while activation of $A C$ by $G \alpha_{s}$ exerts differential effects on PKB activity. In cells expressing Epac, cAMP activates PI 3-K/PKB via Rap1 while, in other cells, cAMP activates PKA that exerts a negative action on PI 3-K and PKB (Mei et al. [148]; Wang et al. [149]).

$\mathrm{G}_{\mathrm{i}}$ protein-mediated activation of PKB can occur through the coupling of the G $\beta \gamma$ subunit to the catalytic subunit of PI 3-K or via growth factor receptor transactivation. Although only p110 $\gamma$ was initially reported to be activated by G $\beta \gamma$ subunits, this feature is also observed for the p110 $\beta$ isoform (Kurosu et al. [150]; Stoyanov et al. [151]). This mechanism is reported in Vero cells where stimulation with LPA activates Ras upon increase in $\mathrm{p} 110 \beta$ lipid kinase activity (Yart et al. [152]). $\mathrm{G}_{\mathrm{i}}$ protein-mediated transactivation of growth factor receptors is reported in $\mathrm{HaCaT}, \mathrm{A}-431$, and HEK293 cells where stimulation of the angiotensin type I receptor by mechanical stress induces transactivation of EGFR leading to activation of the PI 3-K/PKB cascade and protection of these cells from apoptosis (Kippenberger et al. [153]).

In 1321N1 astrocytoma cells, PLC $\beta$ activation by the $G_{q}$ protein-coupled muscarinic $M_{3}$ receptor also triggers PI 3-K activation through ErbB3 transactivation, but this mechanism requires $\mathrm{Ca}^{2+}$ mobilisation (Tang et al. [154]). In contrast, some reports showed an inhibitory pathway from $\mathrm{G}_{\mathrm{q}}$ protein-coupled receptors towards PI $3-\mathrm{K}$ by direct interaction between $\mathrm{G} \alpha$ subunits released from heterotrimeric $G$ proteins and $\mathrm{p} 110 \alpha$, as reported for the $\alpha_{1 \mathrm{~A}}$-AR in rat-1 fibroblasts (Ballou et al. [155, 156]), or by inhibition of insulin receptor substrate-1-associated PI 3-K activity in $1321 \mathrm{~N} 1$ astrocytoma cells by carbachol, histamine or thrombin. These observations reveal opposing effects of muscarinic receptor stimulation on PI 3-K activity mediated by insulin and ErbB3 receptors in these cells (Batty et al. [157]).

Modulation of PI 3-K/PKB signalling is also reported for a few P2Y receptors. In bovine adventitial fibroblasts, ATP is shown to induce proliferation through parallel but independent ERK and PI 3-K signalling cascades that contribute to mTOR and p70S6K phosphorylation (Gerasimovskaya et al. [158]). In rat mesangial cells, stimulation of the $\mathrm{P}_{2} \mathrm{Y}_{2}$ receptor with
ATP or UTP activates PKB by a PDK-1-dependent mechanism while, in C6 cells, ADP activates PI 3-K/ PKB by the $G_{i}$ protein-coupled $P 2 Y_{12}$ receptor but inhibits PI 3-K by stimulation of the $\mathrm{G}_{\mathrm{q}} / \mathrm{G}_{11 / 12}$ proteincoupled $\mathrm{P}_{1} \mathrm{Y}_{1}$ receptor (Table 2) (Van Kolen and Slegers [45]; Czajkowski et al. [46]; Huwiler et al. [159]). Although most effects of P2Y-mediated activation of PI 3-K signalling are known to be related to cell proliferation, differentiation and survival, this signalling cascade is also involved in other processes. In this regard, it can be mentioned that $\mathrm{P}_{2} \mathrm{Y}_{12}$ receptormediated PI 3-K/PKB activation modulates proliferation and differentiation of $\mathrm{C} 6$ cells, but also plays an important role in ADP-induced platelet aggregation (Van Kolen and Slegers [45]; Czajkowski et al. [46]; Chen et al. [160]; Kim et al. [161]).

\section{P2Y receptor-integrated G protein-coupled receptor and receptor tyrosine kinase signalling cascades}

\section{G protein-coupled receptor cross-talk}

Complementary to vertical downstream signalling upon GPCR stimulation, these receptors also mediate lateral signalling by cross-talk with other receptors (reviewed in Cordeaux and Hill [162]). In human platelets, it was reported that $\mathrm{P}_{2} \mathrm{Y}_{12}$ receptor activation potentiates $\mathrm{P}_{2} \mathrm{Y}_{1}$ receptor-mediated $\mathrm{Ca}^{2+}$ signalling, while the $\mathrm{P}_{2} \mathrm{Y}_{1}$ receptor negatively regulates this action (Hardy et al. [163]). In renal mesangial cells, P2Y receptors activated by ATP and UTP induce a rapid desensitisation of the sphingosine-1-phosphate (S1P) receptor by PKC-dependent phosphorylation (Xin et al. [164]). A more complex interplay is observed between $\mathrm{P} 2 \mathrm{Y}$ receptors and 5-HT receptor subtypes. Studies performed in $\mathrm{CHO}$ cells stably expressing $5-\mathrm{HT}_{1 \mathrm{~A}}$ receptors revealed that the responsiveness of this receptor is reduced by a PLD/PKC-dependent phosphorylation upon short $(<5 \mathrm{~min})$ pre-treatment with ATP, while the agonist efficacy of the overexpressed $5-\mathrm{HT}_{1 \mathrm{~B}}$ receptor is not altered. Alternatively, longer treatment with ATP alone attenuates $5-\mathrm{HT}_{1 \mathrm{~B}}$ signalling by a mechanism that requires activation of phospholipase $\mathrm{A}_{2}\left(\mathrm{PLA}_{2}\right)$ (Berg et al. [165]). Furthermore, stimulation of $\mathrm{P} 2 \mathrm{Y}$ receptors can also modulate the release of transmitter molecules, including dopamine, glutamate and serotonin (Bezzi and Voltera [52]; Krugel et al. [166]; Nedergaard et al. [167]). A recently discovered mechanism of GPCR cross-talk is the assembly of a heteromeric receptor complex displaying the pharmacological profile of one receptor and the signalling properties of the other. Such an interaction is reported in 
HEK293 cells overexpressing $\mathrm{A}_{1}$ and $\mathrm{P}_{2} \mathrm{Y}_{1}$ receptors. The heteromeric $\mathrm{A}_{1}-\mathrm{P}_{2} \mathrm{Y}_{1}$ receptor complex inhibits AC through $\mathrm{G}_{\mathrm{i} / \mathrm{o}}$ protein, but displays $\mathrm{P} 2 \mathrm{Y}_{1}$ receptorlike pharmacological properties (Yoshioka et al. [168]).

P2Y receptor-mediated transactivation

Many studies reveal that GPCRs and growth factor receptors share a number of signalling modules (e.g., Raf/MEK/ERK, PI 3-K/PDK/PKB) to transduce their effects. In the past decade, it has become clear that the signalling pathways of both receptor systems are interconnected. Stimulation of a GPCR can induce a rapid tyrosine phosphorylation of RTKs. This transactivation mechanism is reported for many GPCRs and proceeds through the $\mathrm{G} \beta \gamma$ subunit-dependent activation of Src. Src in turn activates RTKs by phosphorylation of specific tyrosines located in their intracellular domains or induction of matrix metalloproteases-dependent release of growth factor receptor ligands, e.g., release of heparin-bound EGF (Luttrell and Luttrell [169]).

Another target for signal integration of GPCRs and RTKs are docking proteins. Although these proteins contain phospho-tyrosine binding domains that interact with phosphorylated tyrosine residues of RTKs, stimulation of GPCRs can induce growth factor receptor-independent phosphorylation of docking proteins by Src (Bisotto and Fixman [170]).

In addition to GPCR-dependent phosphorylation of RTKs, the opposite activation mechanism is also reported. Binding of PDGF to its cognate receptor induces association of PDGFR with the $G_{i}$ proteincoupled S1P receptor. Subsequently, Src is recruited to this complex by G $\beta \gamma$ subunits and phosphorylates Grb-2 associated binder-1 resulting in dynamin II-induced "pinching off" of vesicles involved in endocytosis of PDGF-S1P signalling complexes and subsequent activation of ERK1/2 (Waters et al. [171]).

Cross-talk between RTKs and P2Y receptors is reported in Müller glial cells where ATP exerts its mitogenic effect through transactivation of EGF and PDGF receptors resulting in ERK-dependent enhanced proliferation. In these cells, ATP-induced activation of ERK was abolished by treatment with the RTK autophosphorylation inhibitor tyrphostin (AG1478) (Milenkovic et al. [172]). In rat striatal astrocytes, ATP and bFGF activate ERK and induce astrogliosis by a mechanism that is insensitive to RTK inhibition (Abbracchio et al. [173]; Bolego et al. [174]; Neary et al. [175]). More recently, mechanistic studies performed in 1321N1 astrocytoma cells reveal that the human $\mathrm{P}_{2} \mathrm{Y}_{2}$ receptor interacts with Src and
Pyk2, probably by its proline-rich putative SH3 binding sites (PXXP). This interaction is implicated in $\mathrm{P}_{2} \mathrm{Y}_{2}$ receptor-induced transactivation of EGF, PDGF and VEGF receptors (Liu et al. [176]; Seye et al. [100]). Src inhibition abolishes growth factor receptor transactivation and ERK phosphorylation. Although the rat $\mathrm{P} 2 \mathrm{Y}_{2}$ receptor lacks PXXP motives, tyrosine kinase-dependent activation of ERK upon $\mathrm{P}_{2} \mathrm{Y}_{2}$ receptor stimulation is reported in a few rat cell lines, including C6 and PC12 cells (Soltoff et al. [84]; $\mathrm{Tu}$ et al. [44]). In the latter cases, $\mathrm{P}_{2} \mathrm{Y}_{2}$ receptordependent activation of Pyk2 is mediated by PKC and $\mathrm{Ca}^{2+}$ suggesting that the PXXP sequence is dispensable for $\mathrm{P}_{2} \mathrm{Y}_{2}$ receptor-induced tyrosine phosphorylation of Pyk2 and downstream signalling towards ERK. Moreover, $\mathrm{P}_{2} \mathrm{Y}_{2}$ mutants lacking PXXP-motives are still able to activate ERK demonstrating the existence of other pathways towards phosphorylation of ERK (Liu et al. [176]). Observations made in human endothelial cells, where UTP-induced signalling to ERK was shown to depend on $\mathrm{Ca}^{2+}, \mathrm{PKC}$ and integrin-mediated cell anchorage, already pointed to a pathway distinct from the classical Ras/Raf/MEK/ ERK cascade (Short et al. [177]). Human and mouse $\mathrm{P}_{2} \mathrm{Y}_{2}$ receptors contain a RGD sequence which allows activation of ERK by interaction with $\alpha_{\mathrm{V}} \beta_{3} / \beta_{5}$ integrins followed by $G_{o}$ protein coupling. Since these proteins also mediate cell adhesion and chemotaxis, the observed $\mathrm{P} 2 \mathrm{Y}_{2} / \alpha_{\mathrm{V}} \beta_{3} / \beta_{5}$-interaction also points to a possible function of $\mathrm{P}_{2} \mathrm{Y}_{2}$ receptors in inflammatory responses (Erb et al. [178]).

It is clear that, in analogy with other GPCRs, crosstalk between P2Y and growth factor receptors may occur at different levels of the signal transduction pathway depending on receptor subtypes and on the studied system. For the $\mathrm{P}_{2} \mathrm{Y}_{2}$ receptor, additional transactivation mechanisms are facilitated by the presence of signalling motives (e.g., PXXP or RGD) that allow direct interaction with other signalling components (Src, integrins).

\section{P2Y receptor-activated signal transduction pathways in $\mathbf{C 6}$ glioma cells}

As mentioned above, the final outcome of nucleotidemediated signalling is influenced by ecto-enzymes (Claes and Slegers [17]; Czajkowski and Baranska [18]; Grobben et al. [21, 179]). ATP and ADP hydrolysis to adenosine results in growth inhibition by a mechanism that is not yet fully understood. When nucleotide hydrolysis is prevented, ATP, ADP and $A p_{n} A$ (in particular $A p_{3} A$ and $A p_{4} A$ ) increase cell 
proliferation more than two-fold. Stimulation with 2MeSADP, a P2Y agonist not hydrolysed by the ecto-enzymes present on the plasma membrane of $\mathrm{C} 6$ cells, also results in growth enhancement and inhibition of $\beta$-AR-induced differentiation into astrocyte type II (Claes et al. [39]; Van Kolen and Slegers [45]). The pathways involved in the $\mathrm{P} 2 \mathrm{Y}$ receptor-dependent effects on growth and differentiation of these cells are presented in Figure 1.

Nucleotides stimulate several purinergic receptors that activate the ERK cascade by at least two distinct mechanisms. The $\mathrm{P}_{2} \mathrm{Y}_{2}$ receptor, stimulated by UTP and ATP, enhances ERK phosphorylation through a $\mathrm{PLC} / \mathrm{PKC} / \mathrm{Ras} / \mathrm{Raf} / \mathrm{MEK}$ cascade that is attenuated by inhibition of tyrosine kinases and $\mathrm{Ca}^{2+}$ chelation by BAPTA-AM (Tu et al. [44]). The $\mathrm{Ca}^{2+}$-dependence of the $\mathrm{P}_{2} \mathrm{Y}_{2}$ receptor-mediated activation of ERK suggests the involvement of a cPKC $(\alpha, \beta \mathrm{I}, \beta \mathrm{II}$ or $\gamma)$. It is also shown that ADP stimulates the $\mathrm{P}_{2} \mathrm{Y}_{1}$ receptor and activates ERK through a $\mathrm{Ca}^{2+}$-dependent mechanism (Czajkowski et al. [46]), likely by a similar mechanism as reported for the $\mathrm{P}_{2} \mathrm{Y}_{2}$ receptor (Tu et al. [44]). In addition, it has been shown that ADP can activate ERK by stimulation of the $\mathrm{P}_{2} \mathrm{Y}_{12}$ receptor through a RhoA- and PKC-dependent pathway that does not require $\mathrm{Ca}^{2+}$, Ras or tyrosine kinase activation (Grobben et al. [40]). The fact that $\mathrm{Ca}^{2+}$ removal does not affect $\mathrm{P} 2 \mathrm{Y}_{12}$ receptor-mediated ERK activation excludes the involvement of cPKCs. Stimulation of the $\mathrm{P}_{2} \mathrm{Y}_{12}$ receptor does not induce PI-turnover, but nPKCs might be involved since alternative activation mechanisms, based on Ser/Thr and Tyr phosphorylation, have been reported (Steinberg [180]; Parekh et al. [181]). Data from our laboratory suggest an important role for $\mathrm{PKC} \zeta$ in $\mathrm{P}_{2} \mathrm{Y}_{12}$ receptor-dependent activation of ERK. The fact that no cross-talk between ERK and PI 3-K is observed in $\mathrm{C} 6$ cells indicates that PKC $\zeta$ exerts its actions independently of PI 3-K via a RhoA-

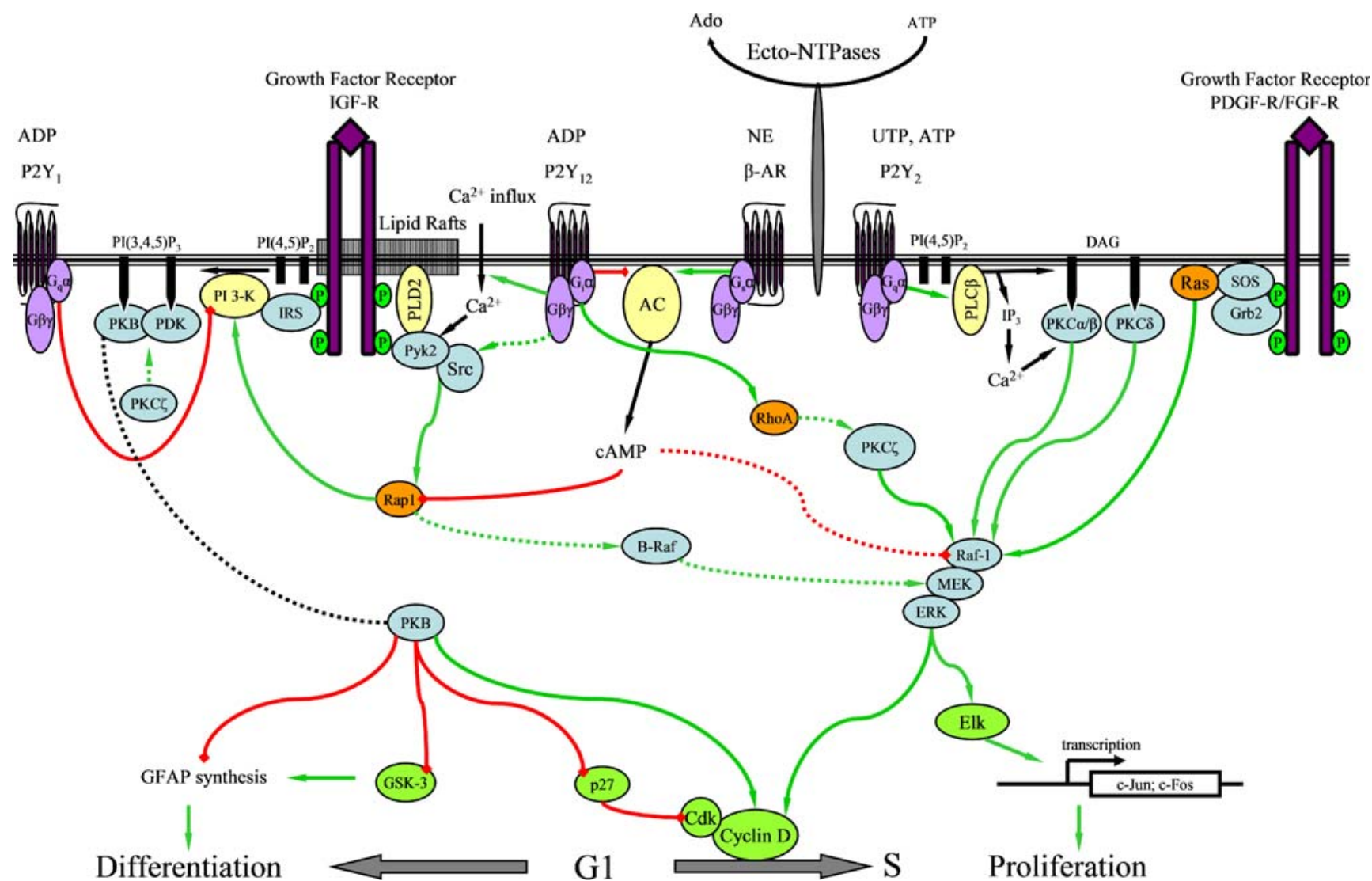

Figure 1 Overview of $\mathrm{P} 2 \mathrm{Y}$ receptor-mediated signalling cascades in C6 cells. Green and red lines represent stimulatory (green arrows) and inhibitory (red squares) actions respectively. Dashed lines are incomplete characterised pathways. $\mathrm{P}_{2} \mathrm{Y}_{2}$ receptor stimulation enhances ERK-dependent proliferation through a PLC-dependent pathway while $\mathrm{P}_{2} \mathrm{Y}_{12}$ receptor stimulation enhances cell proliferation by RhoA- and PKC $\zeta$-dependent activation of ERK (Claes et al. [39]; Grobben et al. [40]; Tu et al. [44]; Van Kolen and Slegers, [199]). P2 $Y_{12}$ receptor stimu- lation also inhibits cAMP-dependent induction of differentiation by reactivation of $\mathrm{PKB}$ which requires Src/Pyk2 complex formation and Rap1 activation. Formation of the Src/Pyk2 complex requires $\mathrm{Ca}^{2+}$ and PLD2 which is constitutively active (Claes et al. [22]; Van Kolen and Slegers [45]; Van Kolen et al. [185]). Cyclic AMP-dependent inhibition of PKB and ERK is suggested to depend on inhibition of Rap1 (Wang et al. [149]). The negative modulation of PI $3-\mathrm{K}$ by the $\mathrm{P}_{2} \mathrm{Y}_{1}$ receptor is only displayed in the presence of serum (Czajkowski et al. [46]) 
dependent mechanism (Grobben et al. [40]; Van Kolen and Slegers, [199]). Although P2Y receptors use different mechanisms to activate ERK, they all converge to increased cell proliferation by enhanced synthesis of c-Myc, c-Jun and c-Fos (Zhang et al. [182]). Progression through the G1/S phase of the cell cycle is due to a decreased expression of $\mathrm{p} 27^{\mathrm{Kip}}$ and increased expression of cyclinD.

While stimulation of ERK signalling by P2Y receptors has been known for several years, the coupling with PI 3-K activation was discovered more recently. When C6 cells are grown in the presence of serum, $\mathrm{P}_{2} \mathrm{Y}_{1}$ receptor signalling predominates and is shown to inhibit PI 3-K (Czajkowski et al. [46]). Upon serum deprivation, $\mathrm{P}_{2} \mathrm{Y}_{1}$ receptor expression decreases while $\mathrm{P}_{2} \mathrm{Y}_{12}$ becomes the main ADP-stimulated receptor that enhances the activity of PI $3-K$ by a $G_{i}$ proteindependent mechanism. These observations demonstrate that, in addition to autocrine growth factor receptor signalling, the constitutive PI $3-\mathrm{K}$ activity in C6 cells is modulated by $\mathrm{P}_{2} \mathrm{Y}_{1}$ and $\mathrm{P}_{2} \mathrm{Y}_{12}$ receptor expression. Another cross-talk at the level of PI 3-K/ $\mathrm{PKB}$ is observed for $\mathrm{P} 2 \mathrm{Y}_{12}$ and $\beta-\mathrm{AR}$. Increase in cAMP upon stimulation of the latter receptor transiently inhibits PKB phosphorylation. Stimulation of the $\mathrm{P}_{2} \mathrm{Y}_{12}$ receptor, which negatively affects $\mathrm{AC}$, does not only counteract this inhibition but even enhances PKB activity in comparison to unstimulated cells, suggesting that $\mathrm{P} 2 \mathrm{Y}_{12}$ receptor-mediated $\mathrm{PI} 3-\mathrm{K} / \mathrm{PKB}$ activation is not only due to its inhibitory effect on AC (Van Kolen and Slegers [45]; Czajkowski et al. [46]; Baranska et al. [183]). In addition to their opposing effects on PI 3-K/PKB signalling, unpublished data of our laboratory revealed similar modulation of ERK signalling by $\mathrm{P}_{2} \mathrm{Y}_{12}$ and $\beta$-AR. Whether the $\mathrm{P}_{2} \mathrm{Y}_{12}$ receptor-mediated reversal of ERK inhibition is involved in the inhibition of $\beta$-AR-induced GFAP synthesis remains to be determined. The observation that stimulation of the cells with UTP activates ERK, but fails to inhibit the $\beta$-AR-induced growth arrest and GFAP synthesis, suggests that ERK activation alone is not sufficient to counteract differentiation (Claes et al. [39]; Tu et al. [44]). Conversely, transfection of C6 cells with constutively active PKB prevented (-)-isoproterenol-induced differentiation indicating that inhibition of PKB signalling is required for cAMP-dependent induction of differentiation. Apparently this observation is in contrast with data showing that cAMPdependent induction of differentiation requires PI 3-K activity which is not inhibited upon a 48-h treatment with dbcAMP (Roymans et al. [34]). This might be explained by the fact that induction of differentiation by stimulation of $\beta$-AR proceeds through transient inhibition of PKB while recovery of this activity is required to prohibit cell death. This hypothesis is confirmed by a recent study where sustained inhibition of PI $3-\mathrm{K} / \mathrm{PKB}$ by cannabinoids is shown to induce apoptosis in C6 cells (Table 2) (Ellert-Miklaszewska et al. [184]). Taken together, $\mathrm{P}_{2} \mathrm{Y}_{12}$ receptor stimulation inhibits cAMP-dependent induction of differentiation by a transient increase in PI 3-K/PKB activity. $\mathrm{Ca}^{2+}$ chelation inhibits the basal PKB activity and $\mathrm{P}_{2} \mathrm{Y}_{12}$ receptor-mediated increase in $\mathrm{PKB}$ phosphorylation. Although $\mathrm{C} 6$ cells also express the $\mathrm{P}_{2} \mathrm{Y}_{2}$ receptor, stimulation with UTP does not enhance the activity of PI 3-K/PKB, which may be explained by a differential coupling to $\mathrm{G}$ protein subtypes. $\mathrm{P}_{2} \mathrm{Y}_{2}$ receptor-mediated signalling proceeds through $\mathrm{G}_{\mathrm{q}}$ proteins while the activation of PDK is $G_{i}$ protein-dependent (Table 2) (Tu et al. [44]; Huwiler et al. [159]). The lack of $G_{i}$ protein coupling of the $\mathrm{P}_{2} \mathrm{Y}_{2}$ receptor in $\mathrm{C} 6$ cells might be a consequence of compartimentalisation into caveolae as reported for some $\mathrm{G}_{\mathrm{q}}$ protein-coupled receptors (Bhatnagar et al. [81]).

Although experiments in $\mathrm{CHO}$ cells reveal that $\mathrm{P}_{2} \mathrm{Y}_{12}$ receptor-induced ERK activation requires PI $3-\mathrm{K} \gamma$ (Soulet et al. [92]), experiments performed with LY294002 or Wortmannin excluded cross-talk between both cascades in C6 cells (Grobben et al. [40]). These differences in signalling mechanisms can be explained by the fact that the latter PI 3-K-isoform is only moderately expressed in C6 cells (Van Kolen and Slegers [45]). The exact mechanism of $\mathrm{P}_{2} \mathrm{Y}_{12}$ receptorinduced PI 3-K/PKB activation is not fully understood, but recent data revealed that Src and Pyk2 are involved in $\mathrm{P}_{2} \mathrm{Y}_{12}$ receptor signalling to PI 3-K (Van Kolen et al., [185]). A similar pathway is observed in PC12 cells where Src, in complex with Pyk2 and PLD2, activates PI 3-K in response to $\mathrm{H}_{2} \mathrm{O}_{2}$ (Banno et al., [186]). Since PLD2 is constitutively active in C6 cells (Bobeszko et al. [187]), a significant role for this enzyme in PI 3-K/ Akt signalling is suggested. Although Soulet et al. [92] reported that transactivation of PDGFR is involved in PI 3-K activation by the $\mathrm{P}_{2} \mathrm{Y}_{12}$ receptor in $\mathrm{CHO}$ cells, the use of receptor kinase inhibitors indicated that PDGFR and EGFR are not transactivated by the P2Y 12 receptor in C6 cells. Alternatively, a Rap1-mediated activation of PI 3-K by the $\mathrm{P}_{2} \mathrm{Y}_{12}$ receptor cannot be excluded. Indeed, PI 3-K is postulated as a downstream effector of Rap1 that is inhibited by an increase in cAMP concentration (Wang et al. [149]). Data from our laboratory indicated a rapid $\mathrm{P}_{2} \mathrm{Y}_{12}$ receptor-induced activation of Rap1 that was abolished by $\mathrm{Ca}^{2+}$ chelation and inhibition of Src/Pyk2 complex formation but not by PI 3-K inhibition (Van Kolen et al. [185]). These results positioned Rap1 downstream of Src/Pyk2 but 
upstream of PI 3-K. In addition, this mechanism involves $\mathrm{G} \beta \gamma$ protein subunits and $\mathrm{Ca}^{2+}$-dependent activation of Pyk2 that requires association to IGF-IR and PLD2 to interact with Src. Although Src and Pyk2 are shown to activate Ras/Raf/MEK/ERK in primary astrocytes (Wang and Reiser [83]), this mechanism did not contribute to $\mathrm{P}_{2} \mathrm{Y}_{12}$ receptor-mediated ERK activation in C6 cells pointing to a physical separation of both cascades (Grobben et al. [40]; Van Kolen and Slegers, [199]). Indeed, the formation of a Pyk2/Src/ PLD2/IGFI-R complex may contribute to compartmentalisation of this signalling pathway that requires intact lipid rafts to be active (Van Kolen et al. [185]). In contrast, in blood platelets Rap1, but also Pyk2 activation by the $\mathrm{P}_{2} \mathrm{Y}_{12}$ receptor, depends on PI 3-K activity but is insensitive to $\mathrm{Ca}^{2+}$ chelation (Lova et al. [96, 97]; Koziak et al. [188]). These findings indicate that different cell specific pathways are involved in $\mathrm{P}^{2} \mathrm{Y}_{12}$ receptor-mediated activation of PI 3-K/PKB and additional research is required to allow full characterisation of these signalling cascades.

\section{Conclusions}

At present, nucleotides are known to regulate a variety of biological processes related to vascular-, immunological- and intestinal functioning. In vitro studies on glial and neuronal cells implicated the P2Y receptoractivated signalling pathways in regulation of cell motility, proliferation, chemotaxis and protection against oxidative stress. Furthermore, investigations on tumoral cells demonstrated that stimulation of $\mathrm{P} 2 \mathrm{Y}$ receptors contribute to tumorigenesis by increasing cell proliferation through ERK and PKB signalling pathways activated by independent mechanisms. From these observations, a role of these receptors as potential targets in clinical applications emerges.

$\mathrm{P} 2 \mathrm{Y}$ receptors modulate these physiological functions by activation of GTPases and direct or indirect activation of protein kinases. Characterisation of the involved receptor(s) and elucidation of $\mathrm{P} 2 \mathrm{Y}$ receptorinduced activation of defined pathways needs to be improved by synthesis of specific P2Y agonists and antagonists.

Studies on P2Y receptor-mediated signalling, discussed in this review, demonstrate that besides vertical signal transduction, lateral cross-talk between growth factor receptors and GPCRs extends the signalling properties of a defined receptor subset. It also becomes clear that signal transduction pathways activated by $\mathrm{P} 2 \mathrm{Y}$ receptors largely depend on the cell type and their environment. On the one hand, cellular specificity is determined by differential expression of signalling proteins, but on the other hand also depends on the assembly of signalling modules. Besides specific protein-protein interactions, intracellular compartmentalisation (e.g., lipid rafts, clathrin-coated vesicles) also contributes to the specificity of receptor signalling. Identification of the signalling modules and cellular compartmentalisation will provide more insight into the $\mathrm{P} 2 \mathrm{Y}$ receptor-activated signalling cascades.

Acknowledgment This work was supported by grants from the Fund for Scientific Research Flanders (HS) and BOF-NOI (HS). K.V.K. is a fellow of the Institute of Scientific Technology (IWT).

\section{References}

1. Drury AN, Szent-Gyorgyi A (1929) The physiological activity of adenine compounds with especial reference to their action upon the mammalian heart. J Physiol 68:213-237

2. Abbracchio MP, Saffrey MJ, Höpker V, Burnstock G (1994) Modulation of astroglial cell proliferation by analogues of adenosine and ATP in primary cultures of rat striatum. Neuroscience 59:67-76

3. Burnstock G, Williams M (2000) P2 purinergic receptors: modulation of cell function and therapeutic potential. J Pharmacol Exp Ther 295:862-869

4. Burnstock G (1993) Physiological and pathological roles of purines: an update. Drug Dev Res 28:195-206

5. Ralevic V, Burnstock G (1998) Receptors for purines and pyrimidines. Pharmacol Rev 50:413-492

6. Burnstock G, Kennedy C (1985) Is there a basis for distinguishing two types of P2-purinoceptors? Gen Pharmacol 16:433-440

7. Abbracchio MP, Burnstock G (1994) Purinoceptors: are there families of $\mathrm{P} 2 \mathrm{X}$ and $\mathrm{P} 2 \mathrm{Y}$ purinoceptors? Pharmacol Ther 64:445-475

8. Fredholm BB, Abbracchio MP, Burnstock G, Daly JW, Harden TK, Jacobson KA, Leff P, Williams M (1994) Nomenclature and classification of purinoceptors. Pharmacol Rev 46:143-156

9. Abbracchio MP, Boeynaems JM, Barnard EA, Boyer JL, Kennedy C, Miras-Portugal MT, King BF, Gachet C, Jacobson KA, Weisman GA, Burnstock G (2003) Characterization of the UDP-glucose receptor (re-named here the $\mathrm{P}_{2} \mathrm{Y}_{14}$ receptor) adds diversity to the $\mathrm{P} 2 \mathrm{Y}$ receptor family. Trends Pharmacol Sci 24:52-55

10. Communi D, Gonzalez NS, Detheux M, Brézillon S, Lannoy V, Parmentier M, Boeynaems JM (2001) Identification of a novel human ADP receptor coupled to $G_{i}$. J Biol Chem 276:41479-41485

11. Hollopeter G, Jantzen HM, Vincent D, Li G, England L, Ramakrishnan V, Yang RB, Nurden P, Nurden A, Julius D, Conley PB (2001) Identification of the platelet ADP receptor targeted by antithrombotic drugs. Nature 409:202-207

12. Zhang FL, Luo L, Gustafson E, Palmer K, Qiao X, Fan X, Yang S, Laz TM, Bayne M, Monsma F Jr (2002) P2Y Y $_{13}$ : identification and characterization of a novel Gai-coupled ADP receptor from human and mouse. J Pharmacol Exp Ther 301:705-713

13. Chambers JK, Macdonald LE, Sarau HM, Ames RS, Freeman K, Foley JJ, Zhu Y, McLaughlin MM, Murdock 
P, McMillan L, Trill J, Swift A, Aiyar N, Taylor P, Vawter L, Naheed S, Szekeres P, Hervieu G, Scott C, Watson JM, Murphy AJ, Duzic E, Klein C, Bergsma DJ, Wilson S, Livi GP (2000) A G protein-coupled receptor for UDP-glucose. J Biol Chem 275:10767-10771

14. Herold CL, Qi AD, Harden TK, Nicholas RA (2004) Agonist versus antagonist action of ATP at the $\mathrm{P}_{2} \mathrm{Y}_{4}$ receptor is determined by the second extracellular loop. J Biol Chem 279:11456-11464

15. Qi A-D, Zambon AC, Insel PA, Nicholas RA (2001) An arginine/glutamine difference at the juxtaposition of transmembrane domain 6 and the third extracellular loop contributes to the markedly different nucleotide selectivities of human and canine $\mathrm{P} 2 \mathrm{Y}_{11}$ receptors. Mol Pharmacol 60:1375-1382

16. Lawson Z, Wheatley M (2004) The third extracellular loop of G-protein-coupled receptors: more than just a linker between two important transmembrane helices. Biochem Soc Trans 32:1048-1050

17. Claes P, Slegers H (2004) P2Y receptor affects the proliferation and differentiation of glial and neuronal cells: a focus on rat C6 glioma cells. Curr Neuropharmacol 2:207-220

18. Czajkowski R, Baranska J (2002) Cross-talk between the ATP and ADP nucleotide receptor signalling pathways in glioma C6 cells. Acta Biochim Pol 49:877-889

19. Goding JW, Grobben B, Slegers H (2003) Physiological and pathophysiological functions of the ecto-nucleotide pyrophosphatase/phosphodiesterase family. Biochim Biophys Acta 1638:1-19

20. Zimmermann H (2000) Extracellular metabolism of ATP and other nucleotides. Naunyn-Schmiedeberg's Arch Pharmacol 362:299-309

21. Grobben B, Claes P, Roymans D, Esmans EL, Van Onckelen H, Slegers H (2000) Ecto-nucleotide pyrophosphatase modulates the purinoceptor-mediated signal transduction and is inhibited by purinoceptor antagonists. Br J Pharmacol 130:139-145

22. Claes P, Van Kolen K, Roymans D, Blero D, Vissenberg K, Erneux C, Verbelen JP, Esmans EL, Slegers H (2004) Reactive blue 2 inhibition of cyclic AMP-dependent differentiation of rat $\mathrm{C} 6$ glioma cells by purinergic receptor-independent inactivation of phosphatidylinositol 3-kinase. Biochem Pharmacol 67:1489-1498

23. Boeynaems JM, van Giezen H, Savi P, Herbert JM (2005) $\mathrm{P} 2 \mathrm{Y}$ receptor antagonists in thrombosis. Curr Opin Investig Drugs 6:275-282

24. Lambrecht G, Braun K, Damer M, Ganso M, Hildebrandt C, Ullmann H, Kassack MU, Nickel P (2002) Structureactivity relationships of suramin and pyridoxal-5' -phosphate derivatives as P2 receptor antagonists. Curr Pharm Des 8:2371-2399

25. Kam PC, Nethery CM (2003) The thienopyridine derivatives (platelet adenosine diphosphate receptor antagonists), pharmacology and clinical developments. Anesthesia 58:28-35

26. Kim YC, Lee JS, Sak K, Marteau F, Mamedova L, Boeynaems JM, Jacobson KA (2005) Synthesis of pyridoxal phosphate derivatives with antagonist activity at the $\mathrm{P}_{2} \mathrm{Y}_{13}$ receptor. Biochem Pharmacol 70:266-274

27. Xu B, Stephens A, Kirschenheuter G, Greslin AF, Cheng X, Sennelo J, Cattaneo M, Zighetti ML, Chen A, Kim SA, Kim HS, Bischofberger N, Cook G, Jacobson KA (2002) Acyclic analogues of adenosine bisphosphates as P2Y receptor antagonists: phosphate substitution leads to multiple pathways of inhibition of platelet aggregation. J Med Chem 45:5694-5709
28. Kubiatowski T, Jang T, Lachyankar MB, Salmonsen R, Nabi RR, Quesenberry PJ, Litofsky NS, Ross AH, Recht LD (2001) Association of increased phosphatidylinositol 3kinase signaling with increased invasiveness and gelatinase activity in malignant gliomas. J Neurosurg 95:480-488

29. Roymans D, Slegers H (2001) Phosphatidylinositol 3kinases in tumor progression. Eur J Biochem 268:487-498

30. Grobben B, De Deyn PP, Slegers H (2002) Rat C6 glioma as experimental model system for the study of glioblastoma growth and invasion. Cell Tissue Res 310:257-270

31. Okumura N, Takimoto K, Okada M, Nakagawa H (1989) C6 glioma cells produce basic fibroblast growth factor that can stimulate their own proliferation. J Biochem 106:904-909

32. Resnicoff M, Sell C, Rubini M, Coppola D, Ambrose D, Baserga R, Rubin R (1994) Rat glioblastoma cells expressing an anti-sense RNA to the insulin-like growth factor-1 (IGF-1) receptor are nontumorigenic and induce regression of wild-type tumors. Cancer Res 54:2218-2222

33. Strawn LM, Mann E, Elliger SS, Chu LM, Germain LL, Niederfellner G, Ullrich A, Shawver LK (1994) Inhibition of glioma cell growth by a truncated platelet-derived growth factor- $\beta$ receptor. J Biol Chem 269:21215-21222

34. Roymans D, Vissenberg K, De Jonghe C, Grobben B, Claes P, Verbelen JP, Van Broeckhoven C, Slegers H (2001) Phosphatidylinositol 3-kinase activity is required for the expression of glial fibrillary acidic protein upon cAMPdependent induction of differentiation in rat C6 glioma. J Neurochem 76:610-618

35. Backhovens H, Gheuens J, Slegers H (1987) Expression of glial fibrillary acidic protein in rat C6 glioma relates to vimentin and is independent of cell-cell contact. J Neurochem 49:348-354

36. Messens J, Slegers H (1992) Synthesis of glial fibrillary acidic protein in rat $\mathrm{C} 6$ glioma in chemically defined medium: cyclic AMP-dependent transcriptional and translational regulation. J Neurochem 58:2071-2080

37. Pianet I, Merle M, Labouesse J (1989) ADP and, indirectly, ATP are potent inhibitors of cAMP production in intact isoproterenol-stimulated C6 glioma cells. Biochem Biophys Res Commun 163:1150-1157

38. Boyer JL, Lazarowski ER, Chen XH, Harden TK (1993) Identification of a $\mathrm{P} 2 \mathrm{Y}$-purinergic receptor that inhibits adenylyl cyclase. J Pharmacol Exp Ther 267:1140-1146

39. Claes P, Grobben B, Van Kolen K, Roymans D, Slegers $\mathrm{H}$ (2001) $\mathrm{P} 2 \mathrm{Y}_{\mathrm{AC}}$-receptor agonists enhance the proliferation of rat C6 glioma cells through activation of the p42/44 mitogen-activated protein kinase. Br J Pharmacol 134:402408

40. Grobben B, Claes P, Van Kolen K, Roymans D, Fransen P, Sys SU, Slegers H (2001) Agonists of the P2Y $\mathrm{AC}_{\text {-receptor }}$ activate MAP kinase by a ras-independent pathway in rat C6 glioma. J Neurochem 78:1325-1338

41. Czajkowski R, Lei L, Sabala P, Baranska J (2002) ADPevoked phospholipase $\mathrm{C}$ stimulation and adenylyl cyclase inhibition in glioma C6 cells occur through two distinct nucleotide receptors, $\mathrm{P}_{2} \mathrm{Y}_{1}$ and $\mathrm{P}_{2} \mathrm{Y}_{12}$. FEBS Lett 513:179_ 183

42. Jin J, Tomlinson W, Kirk IP, Kim YB, Humphries RG, Kunapuli SP (2001) The C6-2B glioma cell P2Y $\mathrm{YC}_{\mathrm{C}}$ is pharmacologically and molecularly identical to the platelet $\mathrm{P}_{2} \mathrm{Y}_{12}$ receptor. Br J Pharmacol 133:521-528

43. Nicholas RA, Lazarowski ER, Watt WC, Li Q, Boyer J, Harden TK (1996) Pharmacological and second messenger signalling selectivities of cloned $\mathrm{P} 2 \mathrm{Y}$ receptors. J Auton Pharmacol 16:319-323 
44. Tu MT, Luo SF, Wang CC, Chien CS, Chiu CT, Lin CC, Yang CM (2000) $\mathrm{P}_{2} \mathrm{Y}_{2}$ receptor-mediated proliferation of $\mathrm{C}_{6}$ glioma cells via activation of Ras/Raf/MEK/MAPK pathway. Br J Pharmacol 129:1481-1489

45. Van Kolen K, Slegers H (2004) $\mathrm{P}_{2} \mathrm{Y}_{12}$ receptor stimulation inhibits $\beta$-adrenergic receptor-induced differentiation by reversing the cyclic AMP-dependent inhibition of protein kinase B. J Neurochem 89:442-453

46. Czajkowski R, Banachewicz W, Ilnytska O, Drobot LB, Baranska J (2004) Differential effects of P2 $Y_{1}$ and P2 $Y_{12}$ nucleotide receptors on ERK1/ERK2 and phosphatidylinositol 3-kinase signalling and cell proliferation in serumdeprived and nonstarved glioma C6 cells. Br J Pharmacol 141:497-507

47. Marteau F, Le Poul E, Communi D, Communi D, Labouret C, Savi P, Boeynaems JM, Gonzalez NS (2003) Pharmacological characterization of the human $\mathrm{P}_{2} \mathrm{Y}_{13}$ receptor. Mol Pharmacol 64:104-112

48. Fumagalli M, Trincavelli L, Lecca D, Martini C, Ciana P, Abbracchio MP (2004) Cloning, pharmacological characterisation and distribution of the rat G-protein-coupled $\mathrm{P} 2 \mathrm{Y}_{13}$ receptor. Biochem Pharmacol 68:113-124

49. Bianco F, Fumagalli M, Pravettoni E, D'Ambrosi N, Volonte C, Matteoli M, Abbracchio MP, Verderio C (2005) Pathophysiological roles of extracellular nucleotides in glial cells: differential expression of purinergic receptors in resting and activated microglia. Brain Res Rev 48:144-156

50. Fumagalli M, Brambilla R, D'Ambrosi N, Volonte C, Matteoli M, Verderio C, Abbracchio MP (2003) Nucleotide-mediated calcium signaling in rat cortical astrocytes: role of P2X and P2Y receptors. Glia 43:203-218

51. Sasaki Y, Hoshi M, Akazawa C, Nakamura Y, Tsuzuki H, Inoue K, Kohsaka S (2003) Selective expression of $\mathrm{G}_{\mathrm{i} / \mathrm{o}^{-}}$ coupled ATP receptor $\mathrm{P}_{2} \mathrm{Y}_{12}$ in microglia in rat brain. Glia 44:242-250

52. Bezzi P, Voltera A (2001) A neuron-glia signalling network in the active brain. Curr Opin Neurobiol 11:387-394

53. Brambilla R, Neary JT, Cattabeni F, Cottini L, D'Ippolito G, Schiller PC, Abbracchio MP (2002) Induction of COX-2 and reactive gliosis by $\mathrm{P} 2 \mathrm{Y}$ receptors in rat cortical astrocytes is dependent on ERK1/2 but independent of calcium signaling. J Neurochem 83:1285-1296

54. Honda S, Sasaki Y, Ohsawa K, Imai Y, Nakamura Y, Inoue K, Kohsaka S (2001) Extracellular ATP or ADP induce chemotaxis of cultured microglia through $\mathrm{G}_{\mathrm{i} / \mathrm{o}}$-coupled P2Y receptors. J Neurosci 21:1975-1982

55. Communi D, Janssens R, Suarez-Huerta N, Robaye B, Boeynaems JM (2000) Advances in signalling by extracellular nucleotides: the role and transduction mechanisms of P2Y receptors. Cell Signal 12:351-360

56. Mirshahi T, Mittal V, Zhang H, Linder ME, Logothetis DE (2002) Distinct sites on $G$ protein $\beta \gamma$ subunits regulate different effector functions. J Biol Chem 277:36345-36350

57. Filippov AK, Webb TE, Barnard EA, Brown DA (1998) $\mathrm{P}_{2} \mathrm{Y}_{2}$ nucleotide receptors expressed heterologously in sympathetic neurons inhibit both $\mathrm{N}$-type $\mathrm{Ca}^{2+}$ and M-type $\mathrm{K}^{+}$currents. J Neurosci 18:5170-5179

58. Filippov AK, Webb TE, Barnard EA, Brown DA (1999) Dual coupling of heterologously-expressed rat $\mathrm{P}_{2} \mathrm{Y}_{6}$ nucleotide receptors to N-type $\mathrm{Ca}^{2+}$ and $\mathrm{M}$-type $\mathrm{K}^{+}$currents in rat sympathetic neurons. Br J Pharmacol 126:1009-1017

59. Filippov AK, Brown DA, Barnard EA (2000) The P2Y receptor closes the $\mathrm{N}$-type $\mathrm{Ca}^{2+}$ channel in neurons, with both adenosine triphosphates and diphosphates as potent agonists. Br J Pharmacol 129:1063-1066
60. Filippov AK, Simon J, Barnard EA, Brown DA (2003) Coupling of the nucleotide $\mathrm{P}_{2} \mathrm{Y}_{4}$ receptor to neuronal ion channels. Br J Pharmacol 138:400-406

61. Simon J, Filippov AK, Göransson S, Wong YH, Frelin C, Michel AD, Brown DA, Barnard EA (2002) Characterization and channel coupling of the $\mathrm{P}_{2} \mathrm{Y}_{12}$ nucleotide receptor of brain capillary endothelial cells. J Biol Chem 277:3139031400

62. Wirkner K, Schweigel J, Gerevich Z, Franke H, Allgaier C, Barsoumian EL, Draheim H, Illes P (2004) Adenine nucleotides inhibit recombinant $\mathrm{N}$-type calcium channels via $G$ protein-coupled mechanisms in HEK 293 cells; involvement of the $\mathrm{P}_{2} \mathrm{Y}_{13}$ receptor-type. $\mathrm{Br} \mathrm{J}$ Pharmacol 141:141-151

63. Filippov AK, Fernandez-Fernandez JM, Marsh SJ, Simon J, Barnard EA, Brown DA (2004) Activation and inhibition of neuronal $\mathrm{G}$ protein-gated inwardly rectifying $\mathrm{K}^{+}$channels by P2Y nucleotide receptors. Mol Pharmacol 66:468-477

64. Suadicani SO, Flores CE, Urban-Maldonado M, Beelitz M, Scemes E (2004) Gap junction channels coordinate the propagation of intercellular $\mathrm{Ca}^{2+}$ signals generated by P2Y receptor activation. Glia 48:217-229

65. Dienel GA, Hertz L (2005) Astrocytic contributions to bioenergetics of cerebral ischemia. Glia 50:362-388

66. Dixon SJ, Yu R, Panupinthu N, Wilson JX (2004) Activation of $\mathrm{P} 2$ nucleotide receptors stimulates acid efflux from astrocytes. Glia 47:367-376

67. Sellers LA, Simon J, Lundahl TS, Cousens DJ, Humphrey PP, Barnard EA (2001) Adenosine nucleotides acting at the human $\mathrm{P}_{2} \mathrm{Y}_{1}$ receptor stimulate mitogen-activated protein kinases and induce apoptosis. J Biol Chem 276:1637916390

68. Fam SR, Paquet M, Castleberry AM, Oller H, Lee CJ, Traynelis SF, Smith Y, Yun CC, Hall RA (2005) $\mathrm{P}_{2} \mathrm{Y}_{1}$ receptor signaling is controlled by interaction with the PDZ scaffold NHERF-2. Proc Natl Acad Sci USA 102:8042-8047

69. Chen BC, Lin WW (1999) PKCbetaI mediates the inhibition of $\mathrm{P} 2 \mathrm{Y}$ receptor-induced inositol phosphate formation in endothelial cells. Br J Pharmacol 127:1908-1914

70. Fam SR, Gallagher CJ, Kalia LV, Salter MW (2003) Differential frequency dependence of $\mathrm{P}_{2} \mathrm{Y}_{1^{-}}$and $\mathrm{P}_{2} \mathrm{Y}_{2^{-}}$ mediated $\mathrm{Ca}^{2+}$ signaling in astrocytes. J Neurosci 23:44374444

71. Pines A, Romanello M, Cesaratto L, Damante G, Moro L, D'andrea P, Tell G (2003) Extracellular ATP stimulates the early growth response protein 1 (Egr-1) via a protein kinase C-dependent pathway in the human osteoblastic HOBIT cell line. Biochem J 373:815-824

72. Hou M, Harden TK, Kuhn CM, Baldetorp B, Lazarowski E, Pendergast W, Moller S, Edvinsson L, Erlinge D (2002) UDP acts as a growth factor for vascular smooth muscle cells by activation of $\mathrm{P}_{2} \mathrm{Y}_{6}$ receptors. Am J Physiol Heart Circ Physiol 282:H784-H792

73. Neary JT, Kang Y, Bu Y, Yu E, Akong K, Peters CM (1999) Mitogenic signaling by ATP/P2Y purinergic receptors in astrocytes: involvement of a calcium-independent protein kinase $\mathrm{C}$, extracellular signal-regulated protein kinase pathway distinct from the phosphatidylinositol-specific phospholipase $\mathrm{C} /$ calcium pathway. J Neurosci 19:4211-4220

74. Wilkin F, Duhant $X$, Bruyns C, Suarez-Huerta N, Boeynaems JM, Robaye B (2001) The P2Y 11 receptor mediates the ATP-induced maturation of human monocyte-derived dendritic cells. J Immunol 166:7172-7177 
75. Nishi H, Kato F, Masaki E, Kawamura M (2002) ADPsensitive purinoceptors induce steroidogenesis via adenylyl cyclase activation in bovine adrenocortical fasciculata cells. Br J Pharmacol 137:177-184

76. Nasu-Tada K, Koizumi S, Inoue K (2005) Involvement of beta1 integrin in microglial chemotaxis and proliferation on fibronectin: different regulations by ADP through PKA. Glia 52:98-107

77. Anderson RG (1998) The caveolae membrane system. Annu Rev Biochem 67:199-225

78. DeFea KA, Zalevsky J, Thoma MS, Déry O, Mullins RD, Bunnet NW (2000) $\beta$-Arrestin-dependent endocytosis of proteinase-activated receptor 2 is required for intracellular targeting of activated ERK1/2. J Cell Biol 148:1267-1281

79. Ostrom RS, Insel P (2004) The evolving role of lipid rafts and caveolae in $\mathrm{G}$ protein-coupled receptor signaling: implications for molecular pharmacology. Br J Pharmacol 143:235-245

80. Kaiser RA, Oxhorn BC, Andrews G, Buxton IL (2002) Functional compartmentation of endothelial $\mathrm{P} 2 \mathrm{Y}$ receptor signaling. Circ Res 23:292-299

81. Bhatnagar A, Sheffler DJ, Kroeze WK, Compton-Toth BA, Roth BL (2004) Caveolin-1 interacts with 5- $\mathrm{HT}_{2 \mathrm{~A}}$ serotonin receptors and profoundly modulates the signaling of selected $\mathrm{G}_{\mathrm{q}}$-coupled protein receptors. J Biol Chem 279:34614-34623

82. Lev S, Moreno H, Martinez R, Canoll P, Peles E, Musacchio JM, Plowman GD, Rudy B, Schlessinger J (1995) Protein tyrosine kinase Pyk2 involved in $\mathrm{Ca}^{2+}$ induced regulation of ion channel and MAP kinase functions. Nature 376:737-745

83. Wang H, Reiser G (2003) The role of the $\mathrm{Ca}^{2+}$-sensitive tyrosine kinase Pyk2 and Src in thrombin signalling in rat astrocytes. J Neurochem 84:1349-1357

84. Soltoff SP, Avraham H, Avraham S, Cantley LC (1998) Activation of $\mathrm{P}_{2} \mathrm{Y}_{2}$ receptors by UTP and ATP stimulates mitogen-activated kinase activity through a pathway that involves related adhesion focal tyrosine kinase and protein kinase C. J Biol Chem 273:2653-2660

85. Ellis CA, Malik AB, Gilchrist A, Hamm H, Sandoval R, Voyno-Yasenetskaya T, Tiruppathi C (1999) Thrombin induces proteinase-activated receptor-1 gene expression in endothelial cells via activation of $\mathrm{G}_{\mathrm{i}}$-linked Ras/mitogenactivated protein kinase pathway. J Biol Chem 274:1371813727

86. Lopez-Ilasaca M, Crespo P, Pellici PG, Gutkind JS, Wetzker R (1997) Linkage of G protein-coupled receptors to the MAPK signaling pathway through PI 3-kinase $\gamma$. Science 275:394-397

87. Bhattacharya M, Babwah AV, Ferguson SS (2004) Small GTP-binding protein-coupled receptors. Biochem Soc Trans 32:1040-1044

88. Bos JL (2005) Linking Rap to cell adhesion. Curr Opin Cell Biol 17:123-128

89. Lutz S, Freichel-Blomquist A, Yang Y, Rumenapp U, Jakobs KH, Schmidt M, Wieland T (2005) The guanine nucleotide exchange factor p63RhoGEF, a specific link between $\mathrm{Gq} / 11$-coupled receptor signaling and RhoA. J Biol Chem 280:11134-11139

90. Walker SA, Cullen PJ, Taylor JA, Lockyer PJ (2003) Control of Ras cycling by $\mathrm{Ca}^{2+}$. FEBS Lett 546:6-10

91. Gao Z, Chen T, Weber MJ, Linden J (1999) $\mathrm{A}_{2 \mathrm{~B}}$ adenosine and $\mathrm{P}_{2} \mathrm{Y}_{2}$ receptors stimulate mitogen-activated protein kinase in human embryonic kidney-293 cells. Cross-talk between cyclic AMP and protein kinase C pathways. J Biol Chem 274:5972-5980
92. Soulet C, Sauzeau V, Plantavid M, Herbert JM, Pacaud P, Payrastre B, Savi P (2004) $\mathrm{G}_{\mathrm{i}}$-dependent and -independent mechanisms downstream of the $\mathrm{P}_{2} \mathrm{Y}_{12}$ ADP-receptor. J Thromb Haemost 2:135-146

93. Woulfe D, Jiang H, Mortensen R, Yang J, Brass LF (2002) Activation of Rap1B by $G_{i}$ family members in platelets. J Biol Chem 277:23382-23390

94. Greco F, Sinigaglia F, Balduini C, Torti M (2004) Activation of the small GTPase Rap2B in agonist-stimulated human platelets. J Thromb Haemost 2:2223-2230

95. Larson MK, Chen H, Kahn ML, Taylor AM, Fabre JE, Mortensen RM, Conley PB, Parise LV (2003) Identification of $\mathrm{P} 2 \mathrm{Y}_{12}$-dependent and -independent mechanisms of glycoprotein activation in platelets. Blood 101:1409-1415

96. Lova P, Paganini S, Sinigaglia F, Balduini C, Torti M (2002) A $\mathrm{G}_{\mathrm{i}}$-dependent pathway is required for activation of the small GTPase Rap1B in human platelets. J Biol Chem 277:12009-12015

97. Lova P, Paganini S, Hirsch E, Barberis L, Wymann M, Sinigaglia F, Balduini C, Torti M (2003) A selective role for phosphatidylinositol 3,4,5-trisphosphate in the $\mathrm{G}_{\mathrm{i}}$-dependent activation of platelet Rap1B. J Biol Chem 278:131-138

98. Paul BZ, Daniel JL, Kunapuli SP (1999) Platelet shape change is mediated by both calcium-dependent and -independent signaling pathways: role of p160 Rho-associated coiled-coil-containing protein kinase in platelet shape change. J Biol Chem 274:28293-28300

99. Sauzeau V, Le Jeune H, Cario-Toumaniantz C, Vaillant N, Gadeau AP, Desgranges C, Scalbert E, Chardin P, Pacaud P, Loirand G (2000) P2 $\mathrm{Y}_{1}, \mathrm{P}_{2} \mathrm{Y}_{2}, \mathrm{P}_{2} \mathrm{Y}_{4}$, and $\mathrm{P} 2 \mathrm{Y}_{6}$ receptors are coupled to Rho and Rho kinase activation in vascular myocytes. Am J Physiol Heart Circ Physiol 278:H1751-H1761

100. Seye CI, Yu N, Gonzalez FA, Erb L, Weisman GA (2004) The $\mathrm{P}_{2} \mathrm{Y}_{2}$ nucleotide receptor mediates vascular cell adhesion molecule-1 expression through interaction with VEGF receptor-2 (KDR/Flk-1). J Biol Chem 279: 35679-35986

101. Dugan LL, Kim JS, Zhang Y, Bart RD, Sun Y, Holtzman DM, Gutmann DH (1999) Differential effects of cAMP in neurons and astrocytes. Role of B-raf. J Biol Chem 274:25842-25848

102. Stork PJ, Schmitt JM (2002) Crosstalk between cAMP and MAP kinase signaling in the regulation of cell proliferation. Trends Cell Biol 12:258-266

103. Qiu W, Zhuang S, von Lintig FC, Boss GR, Pilz RB (2000) Cell type-specific regulation of B-Raf kinase by cAMP and 14-3-3 proteins. J Biol Chem 275:31921-31929

104. Martin NP, Whalen EJ, Zamah MA, Pierce KL, Lefkowitz RJ (2004) PKA-mediated phosphorylation of the $\beta_{1}$-adrenergic receptor promotes $G_{s} / G_{i}$ switching. Cell Signal 16:1397-1403

105. de Rooij J, Zwartkruis FJ, Verheijen MH, Cool RH, Nijman SM, Wittinghofer A, Bos JL (1998) Epac is a Rap1 guanine-nucleotide-exchange factor directly activated by cyclic AMP. Nature 396:474-477

106. de Rooij J, Rehmann H, van Triest M, Cool RH, Wittinghofer A, Bos JL (2000) Mechanism of regulation of the Epac Family of cAMP-dependent RapGEFs. J Biol Chem 275:20829-20836

107. Kawasaki H, Springett GM, Mochizuki N, Toki S, Nakaya N, Matsuda M, Housman DE, Graybiel AM (1998) A family of cAMP-binding proteins that directly activates Rap1. Science 282:2275-2279

108. Laroche-Joubert N, Marsy S, Michelet S, Imbert-Teboul M, Doucet A (2002) Protein kinase A-independent activation 
of ERK and H,K-ATPase by cAMP in native kidney cells: role of Epac I. J Biol Chem 277:18598-18604

109. Lin SL, Johnson-Farley NN, Lubinsky DR, Cowen DS (2003) Coupling of neuronal $5-\mathrm{HT}_{7}$ receptors to activation of extracellular-regulated kinase through a protein kinase A-independent pathway that can utilize Epac. J Neurochem 87:1076-1085

110. Schmitt JM, Stork PJ (2002) G $\alpha$ and G $\beta \gamma$ require distinct Src-dependent pathways to activate Rap1 and Ras. J Biol Chem 277:43024-43032

111. Ebinu JO, Bottorff DA, Chan EY, Stang SL, Dunn RJ, Stone JC (1998) RasGRP, a Ras guanyl nucleotide-releasing protein with calcium- and diacylglycerol-binding motifs. Science 280:1082-1086

112. Agell N, Bachs O, Rocamora N, Villalonga P (2002) Modulation of the Ras/Raf/MEK/ERK pathway by $\mathrm{Ca}^{2+}$ and calmodulin. Cell Signal 14:649-654

113. Kolch W, Heidecker G, Kochs G, Hummel R, Vahidi H, Mischak H, Finkenzeller G, Marmé D, Rapp UR (1996) Protein kinase $\mathrm{C} \alpha$ activates Raf-1 by direct phosphorylation. Nature 364:249-253

114. Yip-Schneider MT, Miao W, Lin A, Barnard DS, Tzivion G, Marshall MS (2000) Regulation of the Raf-1 kinase domain by phosphorylation and 14-3-3 association. Biochem J 351:151-159

115. Cacace AM, Ueffing M, Philipp A, Han EK, Kolch W, Weinstein IB (1996) PKC epsilon functions as an oncogene by enhancing activation of the Raf kinase. Oncogene 13:2517-2526

116. Ueffing M, Lovric J, Philipp A, Mischak H, Kolch W (1997) Protein kinase $\mathrm{C}-\varepsilon$ associates with the Raf-1 kinase and induces the production of growth factors that stimulate Raf-1 activity. Oncogene 15:2921-2927

117. Paruchuri S, Hallberg B, Juhas M, Larsson C, Sjolander A (2002) Leukotriene $\mathrm{D}_{4}$ activates MAPK through a Rasindependent but PKC-dependent pathway in intestinal epithelial cells. J Cell Sci 115:1883-1893

118. Ueda Y, Hirai S, Osada S, Suzuki A, Mizuno K, Ohno S (1996) Protein kinase C $\delta$ activates the MEK-ERK pathway in a manner independent of Ras and dependent on Raf. J Biol Chem 271:23512-23519

119. Nadal-Wollbold F, Pawlowski M, Levy-Toledano S, Berrou E, Rosa JP, Bryckaert M (2002) Platelet ERK2 activation by thrombin is dependent on calcium and conventional protein kinases $\mathrm{C}$ but not Raf-1 or B-Raf. FEBS Lett 531:475-482

120. Takeda H, Matozaki T, Takada T, Noguchi T, Yamao T, Tsuda M, Ochi F, Fukunaga K, Inagaki K, Kasuga M (1999) PI 3-kinase $\gamma$ and protein kinase $\mathrm{C}-\zeta$ mediate RASindependent activation of MAP kinase by a $G_{i}$ proteincoupled receptor. EMBO J 18:386-395

121. Zhao Y, Liu J, Li L, Liu L, Wu L (2005) Role of Ras/PKC // MEK/ERK1/2 signaling pathway in angiotensin II-induced vascular smooth muscle cell proliferation. Regul Pept $128: 43-50$

122. Schönwasser DC, Marais RM, Marshall CJ, Parker PJ (1998) Activation of the mitogen-activated protein kinase/ extracellular signal-regulated kinase pathway by conventional, novel and atypical protein kinase $\mathrm{C}$ isotypes. Mol Cell Biol 18:790-798

123. Corbit KC, Trakul N, Eves EM, Diaz B, Marshall M, Rosner MR (2003) Activation of Raf-1 signaling by protein kinase $\mathrm{C}$ through a mechanism involving Raf kinase inhibitory protein. J Biol Chem 278:13061-13068

124. Van Der Hoeven PC, Van Der Wal JC, Ruurs P, Van Blitterswijk WJ (2000) Protein kinase C activation by acidic proteins including 14-3-3. Biochem J 347:781-785
125. Neary JT, Zhu Q (1994) Signalling by ATP receptors in astrocytes. Neuroreport 5:1617-1620

126. King BF, Neary JT, Zhu Q, Wang S, Norenberg MD, Burnstock G (1996) P2 purinoceptors in rat cortical astrocytes: expression, calcium-imaging and signalling studies. Neuroscience 74:1187-1196

127. Graham A, McLees A, Kennedy C, Gould GW, Plevin R (1996) Stimulation by the nucleotides, ATP and UTP of mitogen-activated protein kinase in EAhy 926 endothelial cells. Br J Pharmacol 117:1341-1347

128. Huwiler A, Pfeilschifter J (1994) Stimulation by extracellular ATP and UTP of the mitogen-activated protein kinase cascade and proliferation of rat mesangial cells. $\mathrm{Br} \mathrm{J}$ Pharmacol 113:1455-1463

129. Erlinge D (1998) Extracellular ATP: a growth factor for vascular smooth muscle cells. Gen Pharmacol 31:1-8

130. Tornquist K, Ekokoski E, Dugue B (1996) Purinergic agonist ATP is a comitogen in thyroid FRTL-5 cells. J Cell Physiol 166:241-248

131. Kim SG, Gao ZG, Soltysiak KA, Chang TS, Brodie C, Jacobson KA (2003) $\mathrm{P}_{2} \mathrm{Y}_{6}$ nucleotide receptor activates $\mathrm{PKC}$ to protect $1321 \mathrm{~N} 1$ astrocytoma cells against tumor necrosis factor-induced apoptosis. Cell Mol Neurobiol 23:401-418

132. Way KJ, Chou E, King GL (2000) Identification of PKCisoform-specific biological actions using pharmacological approaches. Trends Pharmacol Sci 21:181-187

133. Harper S, Webb TE, Charlton SJ, Ng LL, Boarder MR (1998) Evidence that $\mathrm{P}_{2} \mathrm{Y}_{4}$ receptors are involved in the regulation of rat aortic smooth muscle cells by UTP and ATP. Br J Pharmacol 124:703-710

134. Ahmad S, Ahmad A, Ghosh M, Leslie CC, White CW (2004) Extracellular ATP-mediated signaling for survival in hyperoxia-induced oxidative stress. J Biol Chem 279:1631716325

135. Meshki J, Tuluc F, Bredetean O, Ding Z, Kunapuli SP (2004) Molecular mechanism of nucleotide-induced primary granule release in human neutrophils: role for the $\mathrm{P}_{2} \mathrm{Y}_{2}$ receptor. Am J Physiol Cell Physiol 286:264-271

136. Berenbaum F, Humbert L, Bereziat G, Thirion S (2003) Concomitant recruitment of ERK1/2 and p38 MAPK signalling pathway is required for activation of cytoplasmic phospholipase A2 via ATP in articular chondrocytes. J Biol Chem 278:13680-13687

137. Brazil DP, Park J, Hemmings BA (2002) PKB binding proteins: getting in on the Akt. Cell 111:293-303

138. Cantley LC (2002) The phosphoinositide 3-kinase pathway. Science 296:1655-1657

139. Leevers SJ, Vanhaesebroeck B, Waterfield MD (1999) Signaling through phosphoinositide 3-kinases: the lipids take centre stage. Curr Opin Cell Biol 11:219-225

140. Woodgett JR (2005) Recent advances in the protein kinase B signaling pathway. Curr Opin Cell Biol 17:150-157

141. Yano S, Tokumitsu H, Soderling TR (1998) Calcium promotes cell survival through $\mathrm{CaM}-\mathrm{K}$ kinase activation of the protein-kinase-B pathway. Nature 396:584-587

142. Dickenson JM (2002) Stimulation of protein kinase B and p70 S6 kinase by the histamine H1 receptor in DDT1MF-2 smooth muscle cells. Br J Pharmacol 135:1967-1976

143. Franke TF, Yang SI, Chan TO, Datta K, Kazlauskas A, Morrison DK, Kaplan DR, Tsichlis PN (1995) The protein kinase encoded by the Akt proto-oncogene is a target of the PDGF-activated phosphatidylinositol 3-kinase. Cell 81:727-736

144. Iacovelli L, Bruno V, Salvatore L, Melchiorri D, Gradini R, Caricasole A, Barletta E, De Blasi A, Nicoletti F (2002) Native group-III metabotropic glutamate receptors are 
coupled to the mitogen-activated protein kinase/phosphatidylinositol-3-kinase pathways. J Neurochem 82:216-223

145. Murga C, Laguinge L, Wetzker R, Cuadrado A, Gutkind JS (1998) Activation of Akt/protein kinase B by G proteincoupled receptors. A role for $\alpha$ and $\beta \gamma$ subunits of heterotrimeric $\mathrm{G}$ proteins acting through phosphatidylinositol-3-OH kinase $\gamma$. J Biol Chem 273:19080-19085

146. Sanchez MG, Ruiz-Llorente L, Sanchez AM, Diaz-Laviada I (2003) Activation of phosphoinositide 3-kinase/PKB pathway by $\mathrm{CB}_{1}$ and $\mathrm{CB}_{2}$ cannabinoid receptors in prostate PC-3 cells. Involvement in Raf-1 stimulation and NGF induction. Cell Signal 15:851-859

147. Bommakanti RK, Vinayak S, Simonds WF (2000) Dual regulation of Akt/Protein Kinase B by heterotrimeric G protein subunits. J Biol Chem 275:38870-38876

148. Mei FC, Qiao J, Tsygankova OM, Meinkoth JL, Quilliam LA, Cheng X (2002) Differential signaling of cyclic AMP: opposing effects of exchange protein directly activated by cyclic AMP and cAMP-dependent protein kinase on protein kinase B activation. J Biol Chem 277:11497-11504

149. Wang L, Liu F, Adamo ML (2001) Cyclic AMP inhibits extracellular signal-regulated kinase and phosphatidylinositol 3-kinase/Akt pathways by inhibiting Rap1. J Biol Chem 276:37242-37249

150. Kurosu H, Maehama T, Okada T, Yamamoto T, Hoshino S, Fukui Y, Ui M, Hazeki O, Katada T (1997) Heterodimeric phosphoinositide 3-kinase consisting of p85 and p110 $\beta$ is synergistically activated by the $\beta \gamma$ subunits of $G$ proteins and phosphotyrosyl peptide. J Biol Chem 272:24252-24256

151. Stoyanov B, Volinia S, Hanck T, Rubio I, Loubtchenkov M, Malek D, Stoyanova S, Vanhaesebroeck B, Dhand R, Nürnberg B, Gierschik P, Seedorf K, Hsuan JJ, Waterfield MD, Wetzker R (1995) Cloning and characterization of a $\mathrm{G}$ protein-activated human phosphoinositide-3 kinase. Science 269:690-693

152. Yart A, Roche S, Wetzker R, Laffargue M, Tonks N, Mayeux P, Chap H, Raynal P (2002) A function for phosphoinositide 3 -kinase $\beta$ lipid products in coupling $\beta \gamma$ to Ras activation in response to lysophosphatidic acid. J Biol Chem 277:21167-21178

153. Kippenberger S, Loitsch S, Guschel M, Muller J, Knies Y, Kaufmann R, Bernd A (2005) Mechanical stretch stimulates protein kinase $\mathrm{B} / \mathrm{Akt}$ phosphorylation in epidermal cells via angiotensin II type 1 receptor and epidermal growth factor receptor. J Biol Chem 280:3060-3067

154. Tang X, Batty IH, Downes CP (2002) Muscarinic receptors mediate phospholipase $\mathrm{C}$-dependent activation of protein kinase $\mathrm{B}$ via $\mathrm{Ca}^{2+}$, ErbB3, and phosphoinositide 3-kinase in 1321N1 astrocytoma cells. J Biol Chem 277:338-344

155. Ballou LM, Cross ME, Huang S, McReynolds EM, Zhang BX, Lin RZ (2000) Differential regulation of the phosphatidylinositol 3-kinase/Akt and p70 S6 kinase pathways by the $\alpha_{1 \mathrm{~A}}$-adrenergic receptor in rat- 1 fibroblasts. $\mathrm{J}$ Biol Chem 275:4803-4809

156. Ballou LM, Lin H-Y, Fan G, Jiang Y-P, Lin RZ (2003) Activated $\mathrm{G} \alpha_{\mathrm{q}}$ inhibits $\mathrm{p} 110 \alpha$ phosphatidylinositol 3-kinase and Akt. J Biol Chem 278:23472-23479

157. Batty IH, Fleming IN, Downes CP (2004) Muscarinicreceptor-mediated inhibition of insulin-like growth factor-1 receptor-stimulated phosphoinositide 3-kinase signalling in 1321N1 astrocytoma cells. Biochem J 379:641-651

158. Gerasimovskaya EV, Tucker DA, Weiser-Evans M, Wenzlau JM, Klemm DJ, Banks M, Stenmark KR (2005) Extracellular ATP-induced proliferation of adventitial fibroblasts requires phosphoinositide 3-kinase, Akt, mam- malian target of rapamycin, and p70 S6 kinase signaling pathways. J Biol Chem 280:1838-1848

159. Huwiler A, Rolz W, Dorsch S, Ren S, Pfeilschifter J (2002) Extracellular ATP and UTP activate the protein kinase B/ Akt cascade via the $\mathrm{P}_{2} \mathrm{Y}_{2}$ purinoceptor in renal mesangial cells. Br J Pharmacol 136:520-529

160. Chen J, De S, Damron DS, Chen WS, Hay N, Byzova TV (2004) Impaired platelet responses to thrombin and collagen in AKT-1-deficient mice. Blood 104:1703-1710

161. Kim S, Jin J, Kunapuli SP (2004) Akt activation in platelets depends on $G_{i}$ signaling pathways. J Biol Chem 279:41864195

162. Cordeaux Y, Hill SJ (2002) Mechanisms of cross-talk between G-protein-coupled receptors. Neurosignals 11:45-57

163. Hardy AR, Jones ML, Mundell SJ, Poole AW (2004) Reciprocal cross-talk between $\mathrm{P}_{2} \mathrm{Y}_{1}$ and $\mathrm{P} 2 \mathrm{Y}_{12}$ receptors at the level of calcium signaling in human platelets. Blood 104:1745-1752

164. Xin C, Ren S, Pfeilschifter J, Huwiler A (2004) Heterologous desensitization of the sphingosine-1-phosphate receptors by purinoceptor activation in renal mesangial cells. $\mathrm{Br}$ J Pharmacol 143:581-589

165. Berg KA, Evans KL, Cropper JD, Clarke WP (2003) Temporal regulation of agonist efficacy at 5-hydroxytryptamine $5-\mathrm{HT}_{1 \mathrm{~A}}$ and 5- $\mathrm{HT}_{1 \mathrm{~B}}$ receptors. J Pharmacol Exp Ther 304:200-205

166. Krugel U, Kittner H, Illes P (2001) Mechanisms of adenosine 5 -triphosphate-induced dopamine release in the rat nucleus accumbens in vivo. Synapse 39:222-232

167. Nedergaard M, Takano T, Hansen AJ (2002) Beyond the role of glutamate as a neurotransmitter. Nat Rev Neurosci 3:748-755

168. Yoshioka K, Saitoh O, Nakata H (2001) Heteromeric association creates a P2Y-like adenosine receptor. Proc Natl Acad Sci USA 98:7617-7622

169. Luttrell DK, Luttrell LM (2004) Not so strange bedfellows: G-protein-coupled receptors and Src family kinases. Oncogene 23:7969-7978

170. Bisotto S, Fixman ED (2001) Src-family tyrosine kinases, phosphoinositide 3-kinase and Gab1 regulate extracellular signal-regulated kinase 1 activation induced by the type A endothelin-1 G-protein-coupled receptor. Biochem J 360: 77-85

171. Waters CM, Connell MC, Pyne S, Pyne NJ (2005) c-Src is involved in regulating signal transmission from PDGF $\beta$ receptor-GPCR(s) complexes in mammalian cells. Cell Signal 17:263-277

172. Milenkovic I, Weick M, Wiedemann P, Reichenbach A, Bringmann A (2003) P2Y receptor-mediated stimulation of Muller glial cell DNA synthesis: dependence on EGF and PDGF receptor transactivation. Invest Ophthalmol Vis Sci 44:1211-1220

173. Abbracchio MP, Brambilla R, Ceruti S, Cattabeni F (1999) Signalling mechanisms involved in $\mathrm{P} 2 \mathrm{Y}$ receptor-mediated reactive astrogliosis. Prog Brain Res 120:333-342

174. Bolego C, Ceruti S, Brambilla R, Puglisi L, Cattabeni F, Burnstock G, Abbracchio MP (1997) Characterization of the signalling pathways involved in ATP and basic fibroblast growth factor-induced astrogliosis. $\mathrm{Br} \mathrm{J}$ Pharmacol 121:1692-1699

175. Neary JT, Kang Y, Shi YF (2004) Signalling from nucleotide receptors to protein kinase cascades in astrocytes. Neurochem Res 29:2037-2042

176. Liu J, Liao Z, Camden J, Griffin KD, Garrad RC, SantiagoPerez LI, Gonzalez FA, Seye CI, Weisman GA, Erb L (2004) Src homology 3 binding sites in the $\mathrm{P}_{2} \mathrm{Y}_{2}$ nucleotide 
receptor interact with $\mathrm{Src}$ and regulate activities of Src, proline-rich tyrosine kinase 2, and growth factor receptors. J Biol Chem 279:8212-8218

177. Short SM, Boyer JL, Juliano RL (2000) Integrins regulate the linkage between upstream and downstream events in $\mathrm{G}$ protein-coupled receptor signaling to mitogen-activated protein kinase. J Biol Chem 275:12970-12977

178. Erb L, Liu J, Ockerhausen J, Kong Q, Garrad RC, Griffin K, Neal C, Krugh B, Santiago-Perez LI, Gonzalez FA, Gresham HD, Turner JT, Weisman GA (2001) An RGD sequence in the $\mathrm{P} 2 \mathrm{Y}_{2}$ receptor interacts with $\alpha_{\mathrm{V}} \beta_{3}$ integrins and is required for $\mathrm{G}_{\mathrm{o}}$-mediated signal transduction. $\mathrm{J}$ Cell Biol 153:491-501

179. Grobben B, Anciaux K, Roymans D, Stefan C, Bollen M, Esmans EL, Slegers H (1999) An ecto-nucleotide pyrophosphatase is one of the main enzymes involved in the extracellular metabolism of ATP in rat C6 glioma. J Neurochem 72:826-834

180. Steinberg SF (2004) Distinctive activation mechanisms and functions for protein kinase C $\delta$. Biochem J 384: 449-459

181. Parekh DB, Ziegler W, Parker PJ (2000) Multiple pathways control protein kinase C phosphorylation. EMBO J 19:496503

182. Zhang W, Turner DJ, Segura BJ, Cowles R, Mulholland MW (2000) ATP induces c-fos expression in C6 glioma cells by activation of $\mathrm{P}_{2 \mathrm{Y}}$ receptors. J Surg Res 94:49-55

183. Baranska J, Czajkowski R, Sabala P (2004) Cross-talks between nucleotide receptor-induced signaling pathways in serum-deprived and non-starved glioma C6 cells. Adv Enzyme Regul 44:219-232

184. Ellert-Miklaszewska A, Kaminska B, Konarska L (2005) Cannabinoids down-regulate PI3K/Akt and Erk signal ling pathways and activate proapoptotic function of Bad protein. Cell Signal 17:25-37

185. Van Kolen K, Gilany K, Moens L, Esmans EL, Slegers H (2006) $\mathrm{P}_{2} \mathrm{Y}_{12}$ receptor signalling towards PKB proceeds through IGF-I receptor cross-talk and requires activation of Src, Pyk2 and Rap1. Cell Signal 18:1169-1181

186. Banno Y, Ohguchi K, Matsumoto N, Koda M, Ueda M, Hara A, Dikic I, Nozawa Y (2005) Implication of phospholipase D2 in oxidant-induced phosphoinositide 3-kinase signaling via Pyk2 activation in PC12 cells. J Biol Chem 280:16319-16324

187. Bobeszko M, Krzeminski P, Pomorski P, Dygas A, Baranska J (2004) Expression and regulation of phospholipase D isoforms in sphingosine and phorbol ester-stimulated glioma C6 cells. Biochem Biophys Res Commun 317:689696
188. Koziak K, Kaczmarek E, Park SY, Fu Y, Avraham S, Avraham H (2001) RAFTK/Pyk2 involvement in platelet activation is mediated by phosphoinositide 3-kinase. $\mathrm{Br} \mathrm{J}$ Haematol 114:134-140

189. Boyer JL, Zohn IE, Jacobson KA, Harden TK (1994) Differential effects of P2-purinoceptor antagonists on phospholipase C- and adenylyl cyclase-coupled P2Y-purinoceptors. Br J Pharmacol 113:614-620

190. Boyer JL, Romero-Avila T, Schachter JB, Harden TK (1996) Identification of competitive antagonists of the P2 $\mathrm{Y}_{1}$ receptor. Mol Pharmacol 50:1323-1329

191. Communi D, Govaerts C, Parmentier M, Boeynaems JM (1997) Cloning of a human purinergic P2Y Receptor coupled to phospholipase $\mathrm{C}$ and adenylyl cyclase. J Biol Chem 272:31969-31973

192. Korcok J, Raimundo LN, Du X, Sims SM, Dixon SJ (2005) $\mathrm{P} \mathrm{Y}_{6}$ nucleotide receptors activate NF-KB and increase survival of osteoclasts. J Biol Chem 280:16909-16915

193. Muller CE (2002) P2-pyrimidinergic receptors and their ligands. Curr Pharm Des 8:2353-2569

194. Skelton L, Cooper M, Murphy M, Platt A (2003) Human immature monocyte-derived dendritic cells express the $\mathrm{G}$ protein-coupled receptor GPR105 (KIAA0001, $\mathrm{P}_{2} \mathrm{Y}_{14}$ ) and increase intracellular calcium in response to its agonist, uridine diphosphoglucose. J Immunol 171:19411949

195. Yerxa BR, Sabater JR, Davis CW, Stutts MJ, Lang-Furr M, Picher M, Jones AC, Cowlen M, Dougherty R, Boyer J, Abraham WM, Boucher RC (2002) Pharmacology of INS37217 $\left[\mathrm{P}(1)\right.$-uridine $\left.5^{\prime}\right)-\mathrm{P}(4)-\left(2^{\prime}\right.$-deoxycytidine $\left.5^{\prime}\right)$ tetraphosphate, tetrasodium salt], a next-generation $\mathrm{P}_{2} \mathrm{Y}_{2}$ receptor agonist for the treatment of cystic fibrosis. J Pharmacol Exp Ther 302:871-880

196. Jacobson KA, Costanzi S, Ohno M, Joshi BV, Besada P, Xu B, Tchilibon S (2004) Molecular recognition at purine and pyrimidine nucleotide (P2) receptors. Curr Top Med Chem 4:805819

197. von Kügelgen I (2006) Pharmacological profiles of cloned mammalian P2Y-receptor subtypes. Pharmacol. Ther. (in press doi: 10.1016/j.pharmathera.2005.08.014)

198. Belcheva MM, Haas PD, Tan Y, Heaton VM, Coscia J (2002) The fibroblast growth factor receptor is at the site of convergence between $\mu$-opioid receptor and growth factor signaling pathways in rat C6 glioma cells. J Pharmacol Exp Ther 303:909-918

199. Van Kolen K, Slegers H (2006) Atypical PKC $\zeta$ is involved in RhoA-dependent mitogenic signaling by the $\mathrm{P}_{2} \mathrm{Y}_{12}$ receptor in $\mathrm{C}_{6}$ cells. FEBS J 273:1843-1854 